造構, 㸃酸和飽非

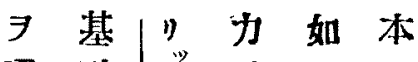

東 證酸|”

京 明人。晲非,

化亞○金悬大飽主

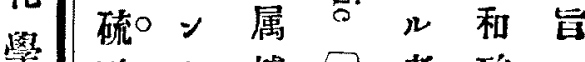

酸。卜盐化者酸心

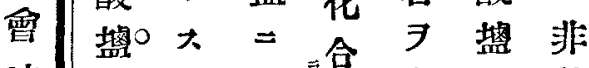

誌|山在荻根会少飽

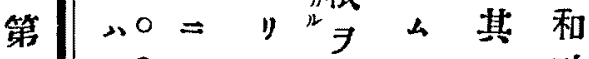

六二只 $=$ 連少, 酸

蛈

オ゚リ八續 故生 垻

キ0 毫大=酸人

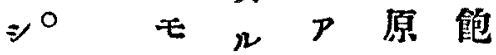

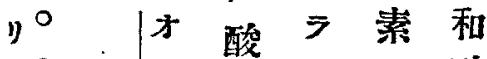

\%

․

s.

象

$\stackrel{4}{\circ}$

to $>$ 義 酸 $\underset{⿱ 中}{\stackrel{8}{E}}+$

no $₹$ 岂, 所

○ \#十饱最以

DU 證。ル和菜心

+0 $=7$ 盐 $\Rightarrow$ 通

三少 $\exists$ 常

Vナり以一鐵

り そモ般吉

卜及材, 兵

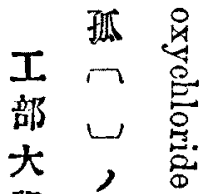

化 非 學

諭燐脃雪

文导和 誌

中角产垻明

括芯范治

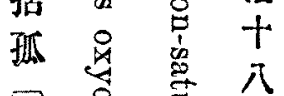

离閳占电

年

校 $\Rightarrow$ 亞 品

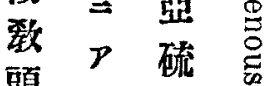

六

月

En

行

頭 酸

占盛密

$\forall$, 双,

工 八亞 構

ド譯 硝 造

ワ

者 酸

清

, 踏 总

+ 一 化 詔譯 速

\& 莺

卢

大盐合,

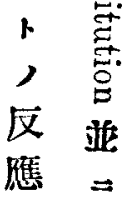

酸

㐭 


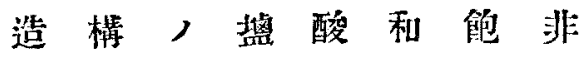

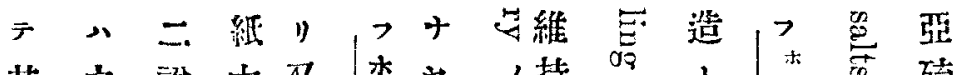

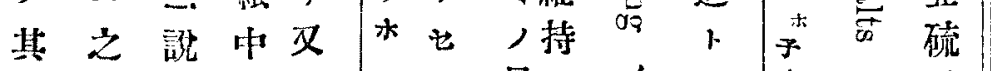

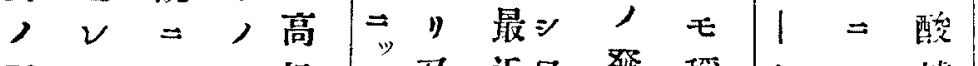

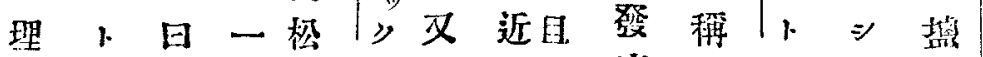
由符》段及棈三人版英賞大此テ,

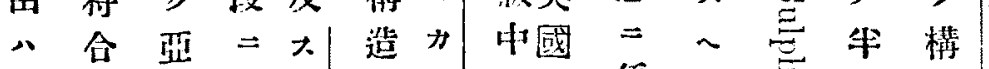
重 せ 硫

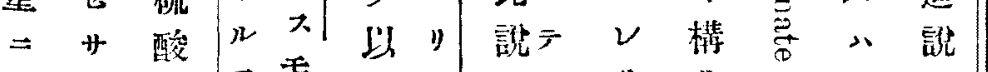

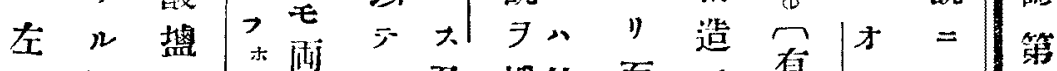

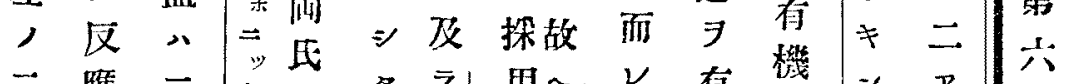

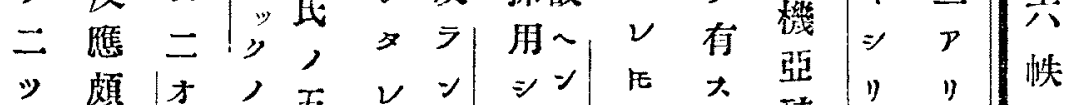
ツ煩|オ人无

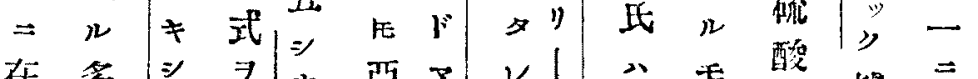

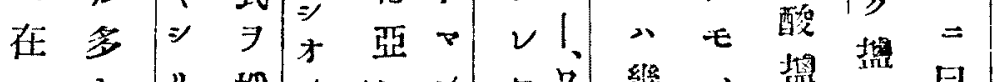

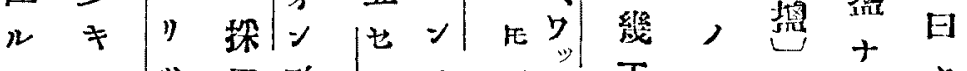
カ $=$ 用酸 $\nu$ 二平

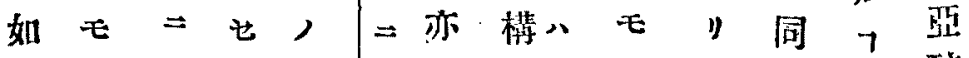

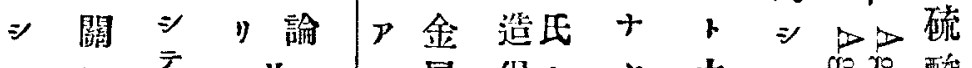

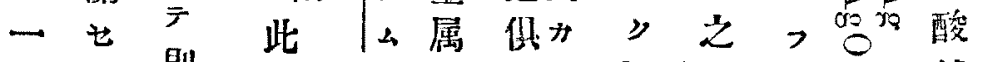

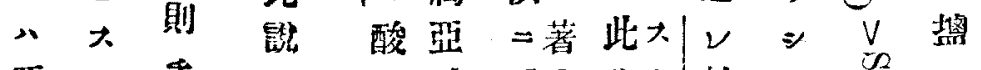

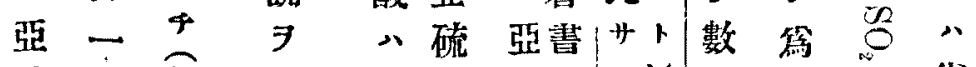

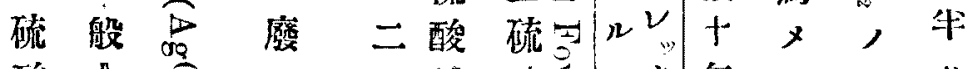

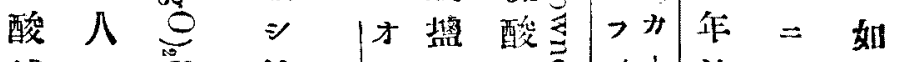

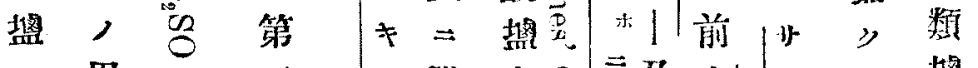

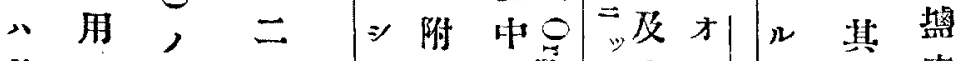
其二 $=$ 如 嵒 叭

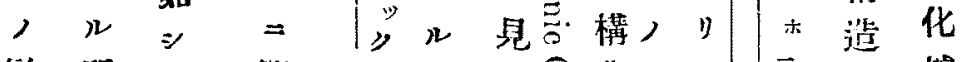

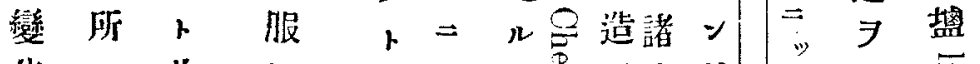

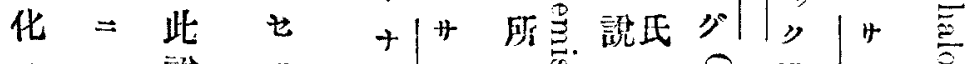

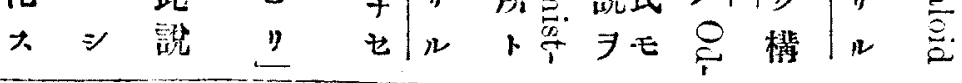




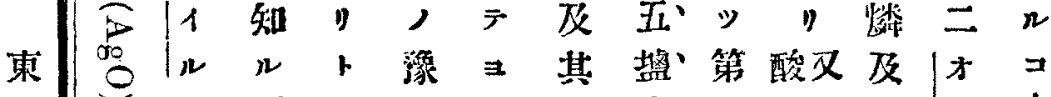

京 学吉所云定”他化二化一酸

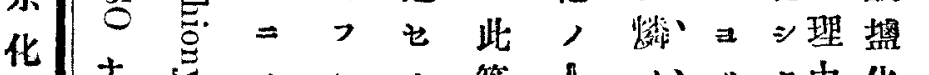

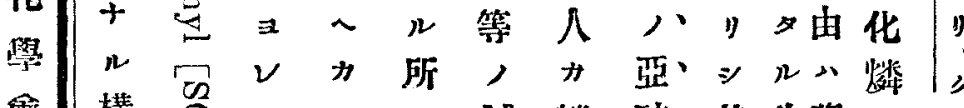

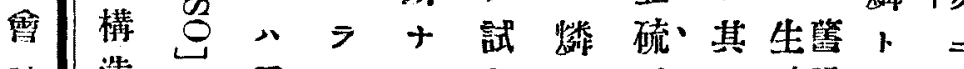

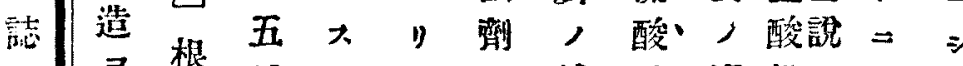

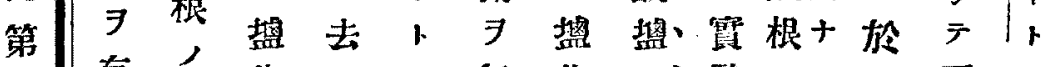

共有二化十踓無化 $\Rightarrow$ 䲆 $\equiv$ 几亞 $\equiv$

蛈 ル

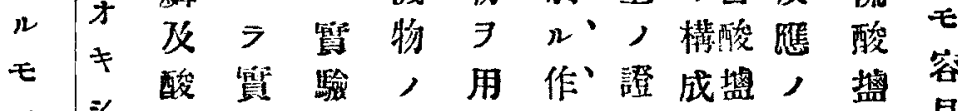

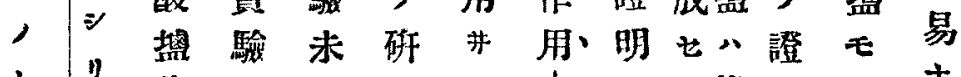

1. $\%$ 化 $\exists$ \&究 $F \mid=$ 皆明亦 +

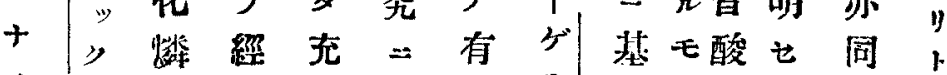

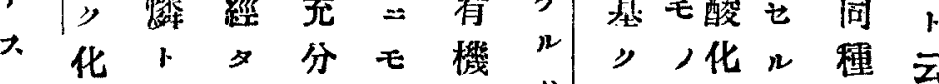

人合, $n+$ 亦酸少, 1 所所類

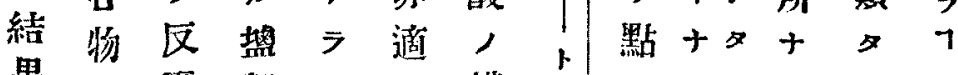

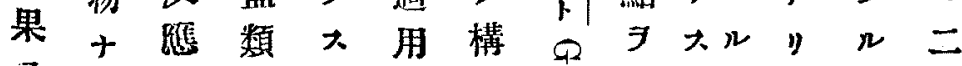

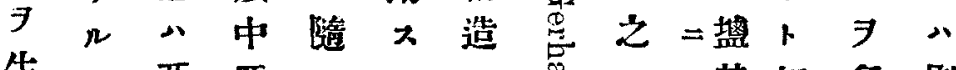

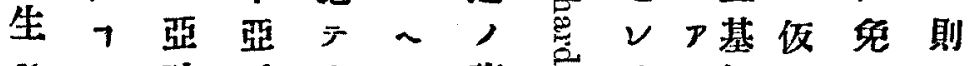

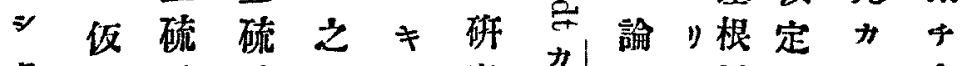
》令酸酸 $レ$ 究办 》八盐堛力, =

亞八刀確、好 万艺 $\nu$ 含 せ 此 $\backsim$ 酸 硫 酸 1 我 $\exists$ 大果 $尺$ 由 是五概 銀才䧳得八

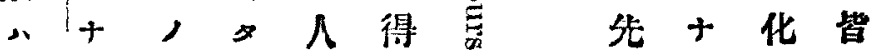




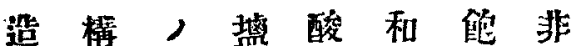

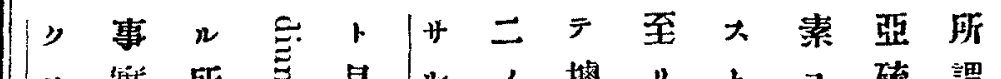

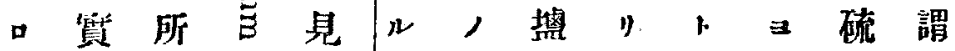

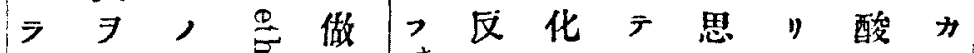

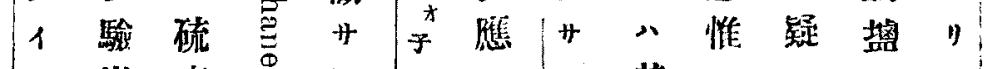
|゙

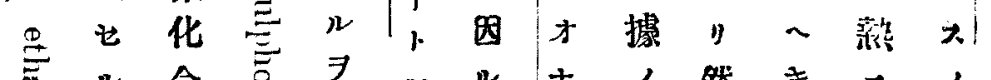
吾， 合

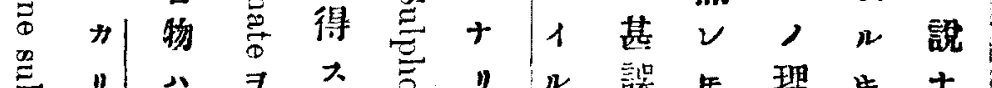

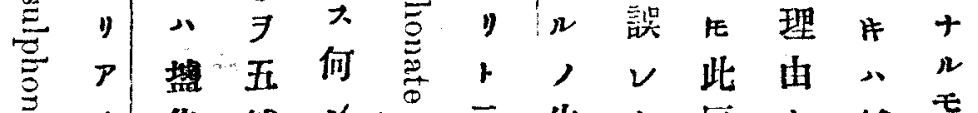

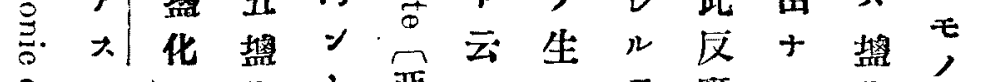

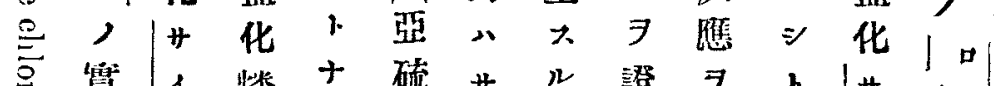
总焉 1 1 燐

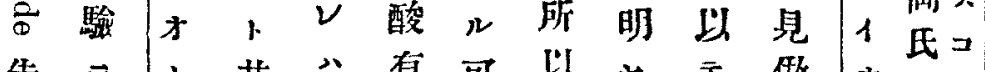

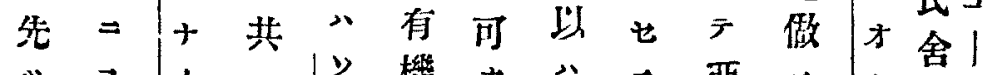

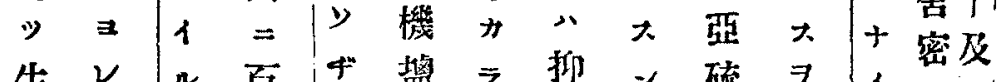
生レ ル 自

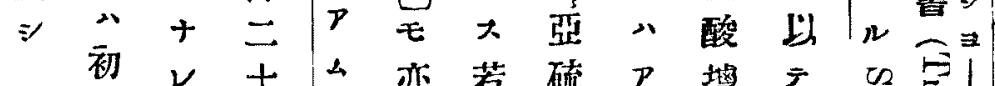
メ

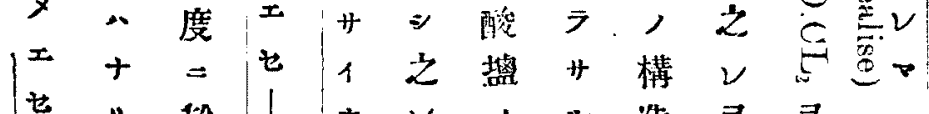

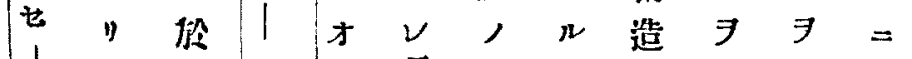

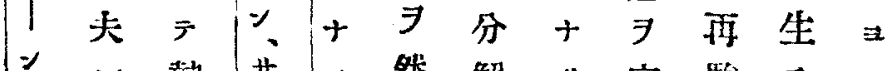
” $v$ 筑

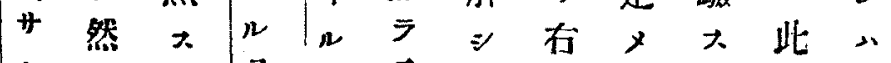

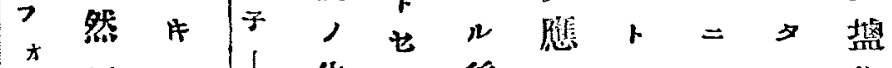

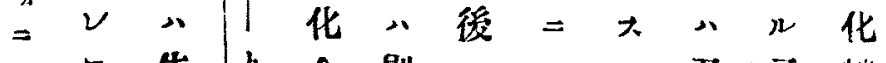
ッ生1上合則,

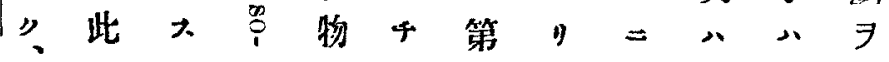


堊ナ酸 ミ|

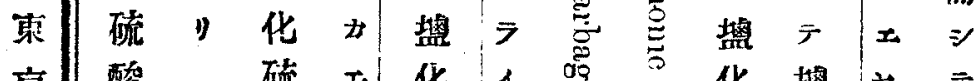

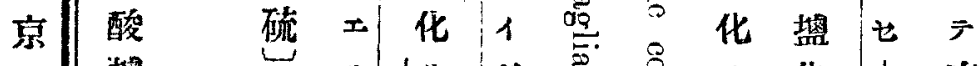

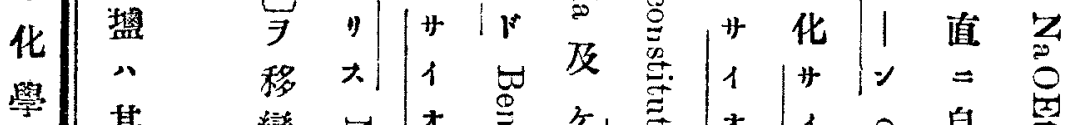

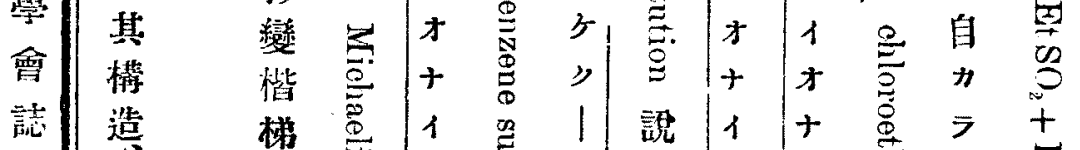

第 |

$\rightarrow 12$

帙 $\mid$\begin{tabular}{c}
7 \\
$\star$ \\
\multirow{3}{*}{}
\end{tabular}

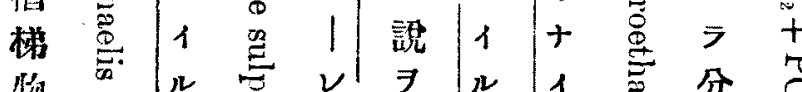

物

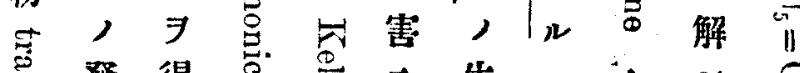

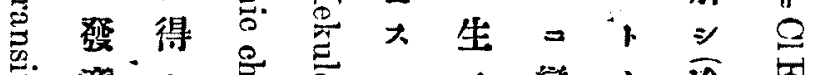

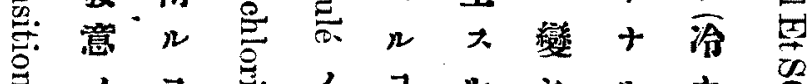

○ノ

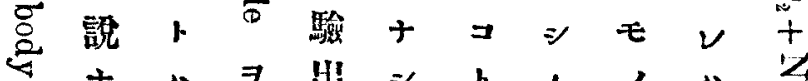

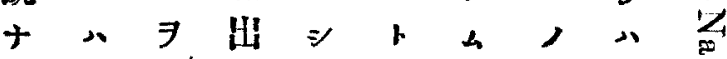

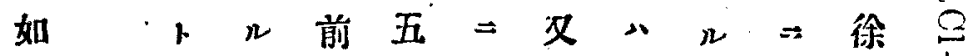

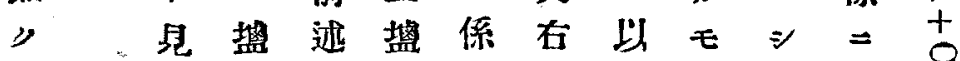

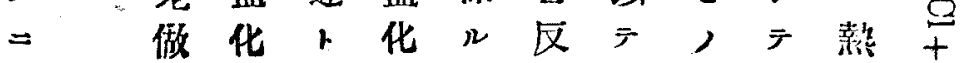

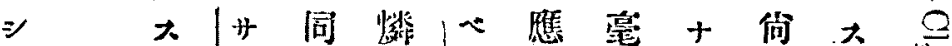

テ 


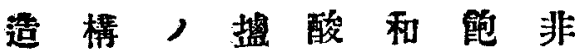

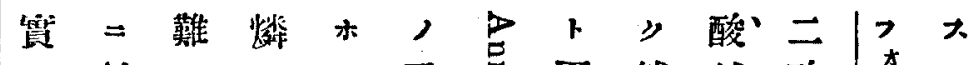

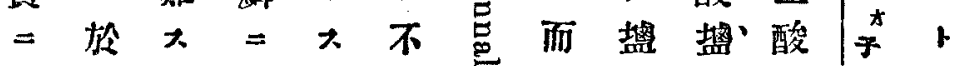

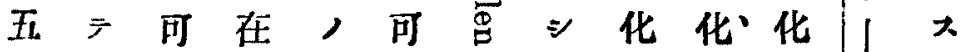

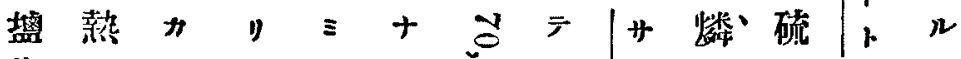

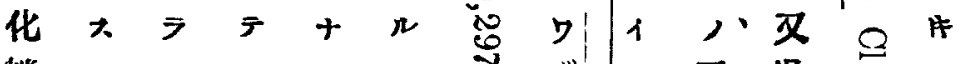
䗲

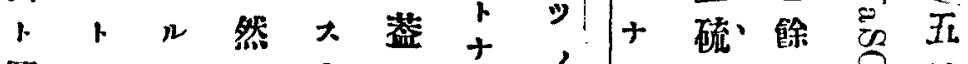
同 $\neq+>$ 亦 $\%$ 大 1 酸,

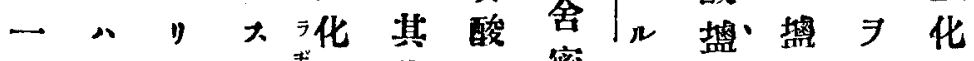

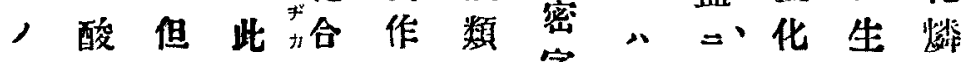

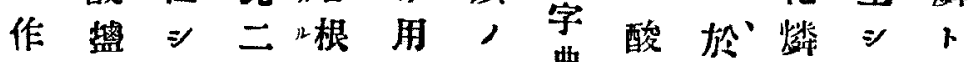
用化非䅅, 八構典堖心、二此, Э 燐常, 酸之造 $三$ 化,

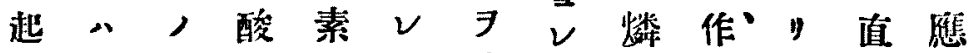
大五填素 $=$ ヨ研八, 用

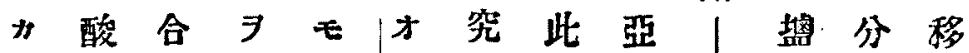

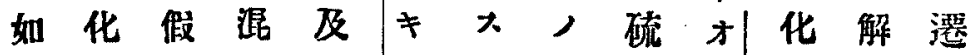

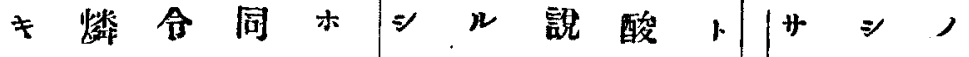
八及

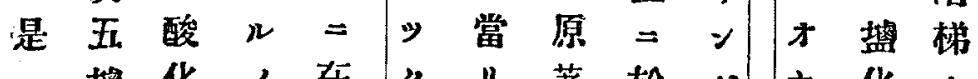
垍化, 在》り著於少十化卜

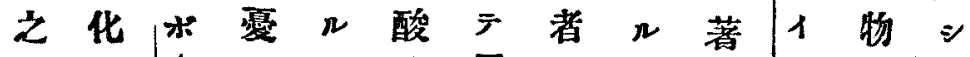
$\checkmark$ 燐|十ナ

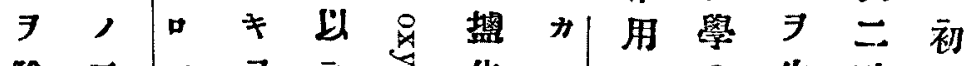

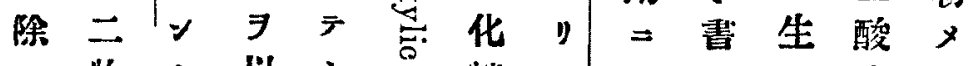

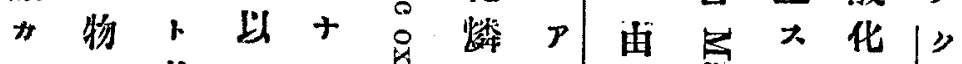

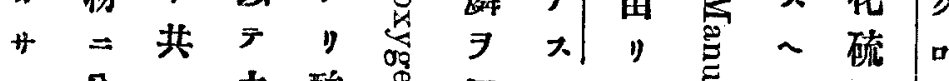
$n$ 分 $=$ 之酸要用 $\Omega \overline{\bar{\Xi}} \neq 1$

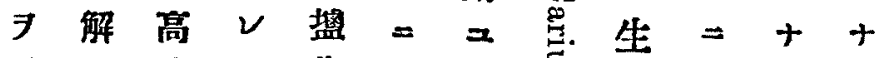

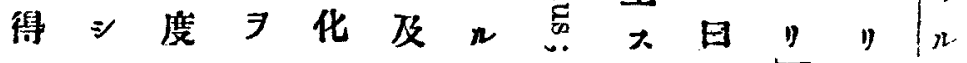




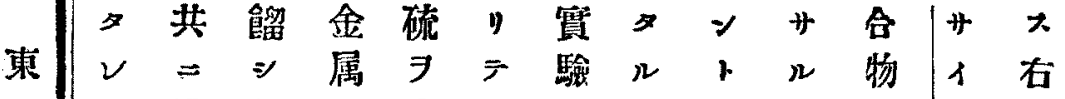
京比逃能, 生之 $=$, $三$,

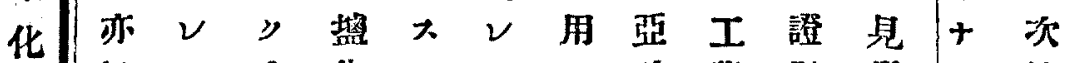

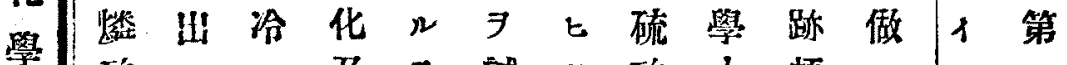
酸 $\Rightarrow$ 及 7 試 雪 $\exists n \Rightarrow$ 燐十驗n䫦清 $⿻, 7 n$

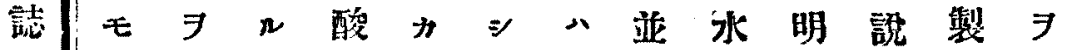
第 現以受琱”》鉛二鐵 $+=$ 以

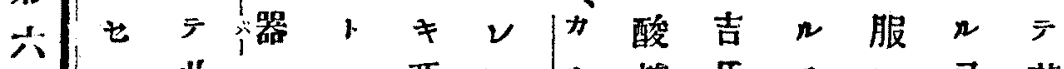

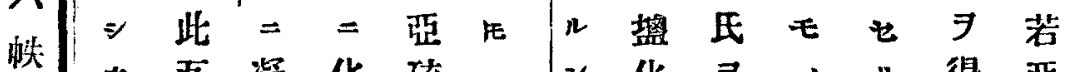
力互凝化硫- $三$ 化 $尹$, サ得亞

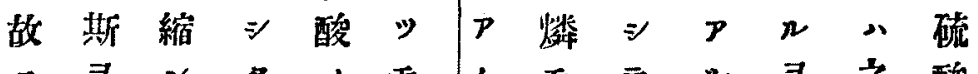
$=\exists=\Rightarrow$, モ

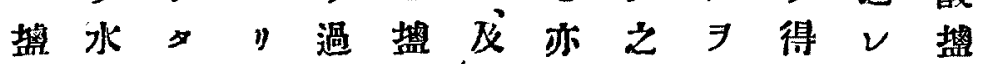
素 $=\nu$ 而牛化 $\mid$ 在 $\nu$ 以 $x$ 亞 $\equiv$

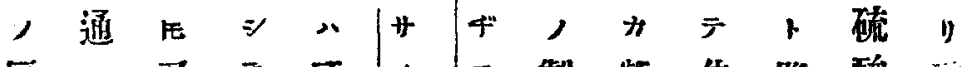
区シ 及テ不

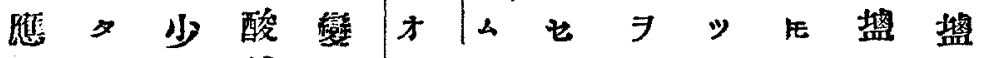

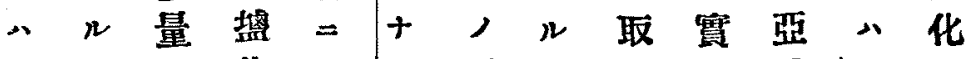
上月八化 $\approx 11$ 亞 所

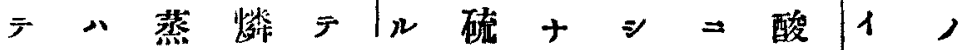

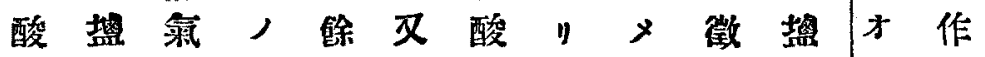

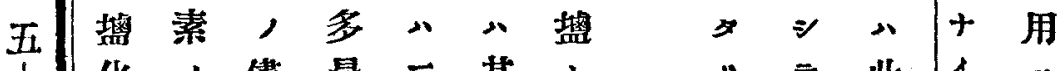
士化, 榓 量二其 + ” 此 $1=$

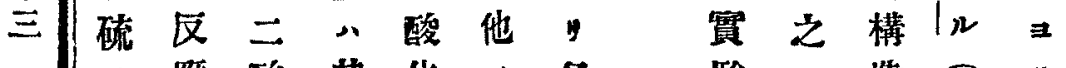
, 應 酸其化, 各驗 $v$ 造 $\bar{D}$ ”

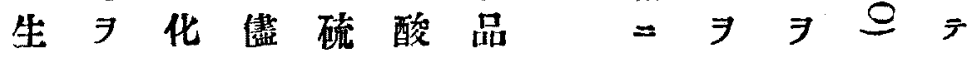
成呈硫 $=$ 卜盐 $\exists$ 用證有人㙞 ᄏ $\approx 1$ 蒸各化取比 七化化 
热热, 示證 右

八土大明,

亞、 $=$ せ

硫、丝

酸、硫 ${ }^{\circ}+ル \Perp \exists$

盐、酸 ${ }^{\circ}+$, 以

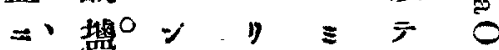

於、 $1=$ 若 + 下.

ル其八

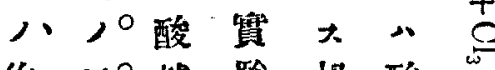

作二盐驗却酸

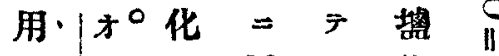

$1 \neq 0$ 燐用其化

留 $=0 \Rightarrow t \mid$ 甘燐

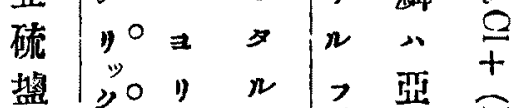

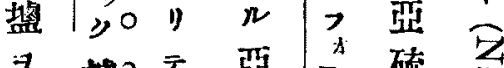

7 笽 テ 亞 ※ 硫

落 $=0$ 毫 硫| 酸

大 $>0$ モ 酸|，搵

$\nu$ >0變䍂構, +

川 \#化 $\exists$ 造|才品

硫 n。 女

化, 0 \# 有 $=$

盐證。”充 オ り

及 $三$ 分 $心$

硫 +乾 モ構

酸

盐 $\quad>\Rightarrow+$

7 n in

生 モ 79 $\gamma$ 卜 化|オ, 徵

云燐大水下

$\therefore$ 中 $1=n$

\# $=n$ 投 $=$

几存,

于 在 生 $;$

得

त $\sim \Rightarrow=n$

因 $\neq \Rightarrow$ 二

テモう酸》

此, У化 双

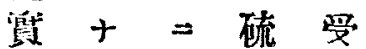

驗 ル 入哭

$=$ 其 $八=$

於右沸硫凝

ル，膯 酸 縮

反反點,

憵憵心区 反

$\therefore+$ 八慰

疑 $\neq+\ni$ 不

七八二呈觼

モ之笼七,

$+\nu+\#$ 酸

其 $ル$ 盐

左生 $カ \approx$ 化

, 女故 若 燐

如 $\#=$ 笭

》 此化 純

士 八酸

證盐 $\left.\right|_{1=}=$ 


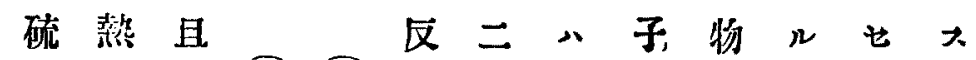

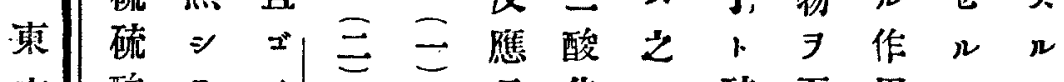

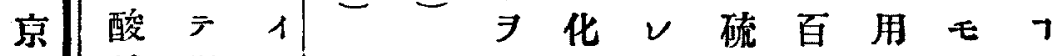

化 盐得 $=$ 孚起硫酸硫九 $=$, “ 學

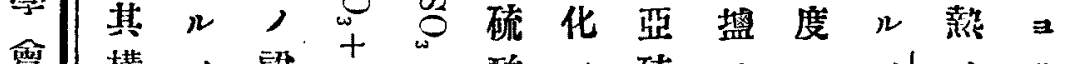

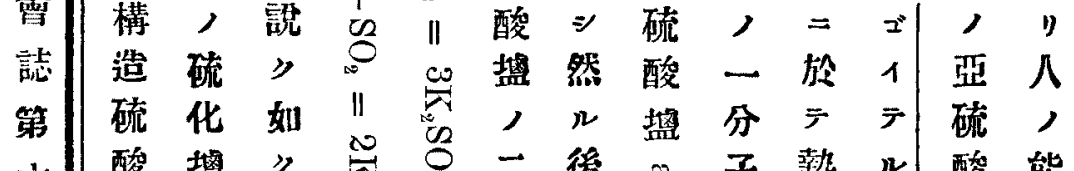

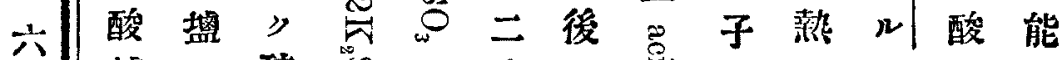
帙 整 $\exists$ 硫员十 , 生硫 + 窟子酸总》n采知

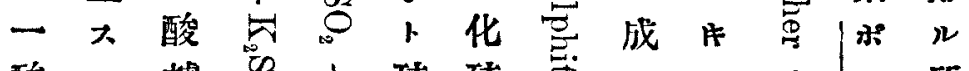
酸盐跑十硫硫宁 $\nu \leadsto,>$ 所

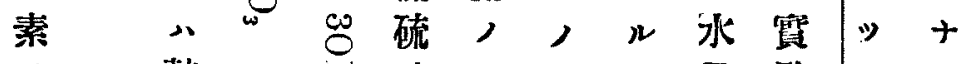

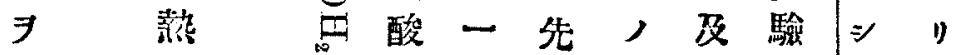

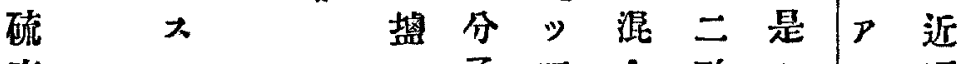
素 $\nu$ 子亞合酸 + A頃 一 卜 硫物化 y +結此 分亞酸 $\ni$ 硫此ル晶變 子硫 正生 $\exists$ 貿 水化

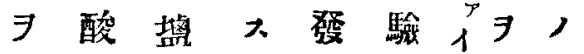
生 正 $\tilde{5}$ 此生 =上有性 大盐总硫 ル, 硫硫レ急ルヨ 二三骂酸酸、言ハ0一

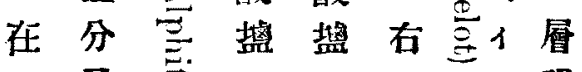
子苦，，，只明 卜水現二化 $=$ 力 , 及出分合於 = 
ニ、硫合カレ合一心酸 小盐

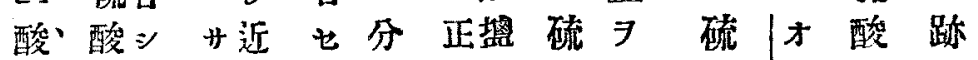

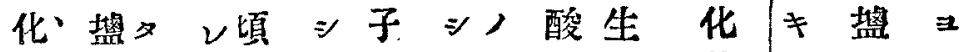

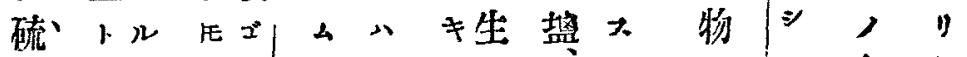

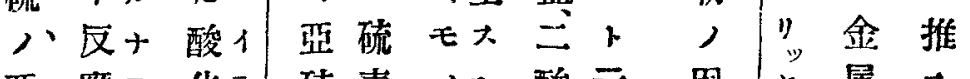
亞、礁ラ化テ硫素ノル酸云因、”属大 硫、フン|P几䣼 $ラ \Rightarrow P$ 化 酸、へ斯 ッ, 正遊 シ

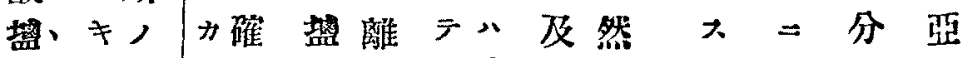

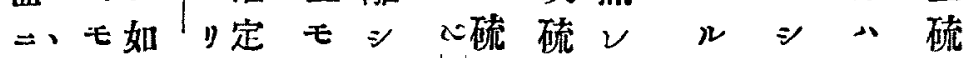
ヨ、ノ,

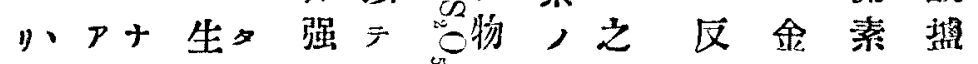
テ、リル成ルク酸 $\|$ 月 分、テカ せ所熱素田得

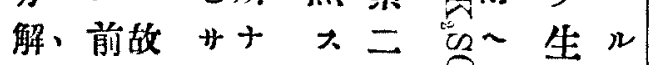

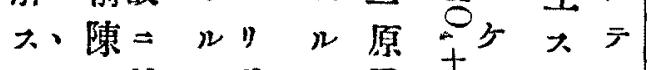

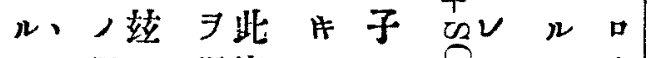

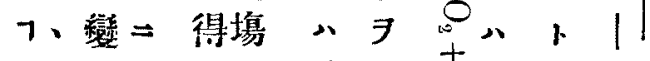

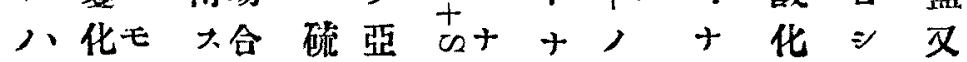

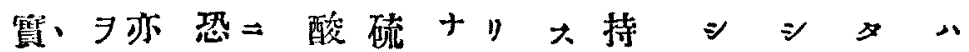

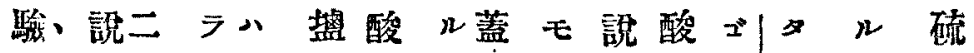

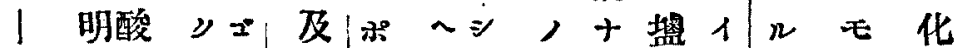

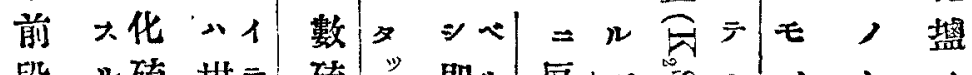

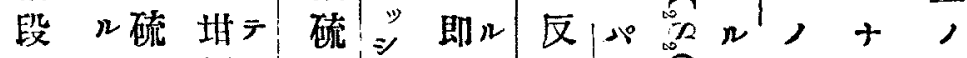

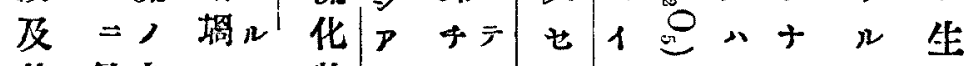

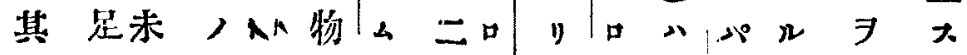

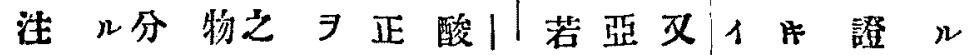
解 一解質レ生盐化ノシ硫硫、心フ、フ

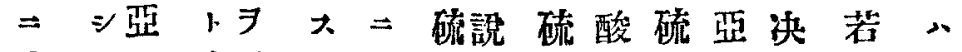
陳化㝃之結, 或硫盐酸硫シ シ 丝 


\section{造構, 㸃酸和能非}

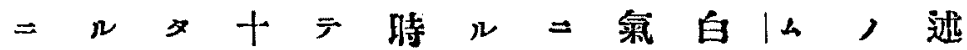

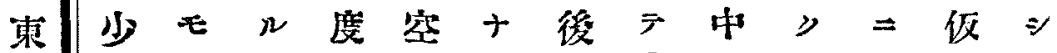
宗量

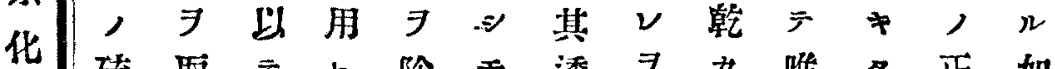
整 硫取 $テ$ 七除モ透 $尹$ カ 唯

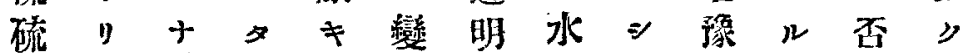

䨛

誌 第 $+1$ 僬

Ii 酸之》ル去化犾 搵 2 右 . . 硫水 如 シ ッ、リ八ス之二硫 せ 硫

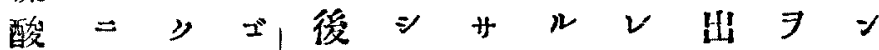
埇投 $=1+$ 又

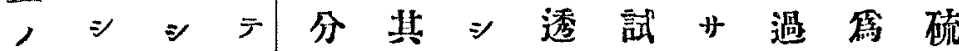

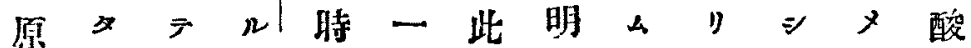

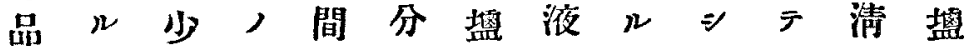

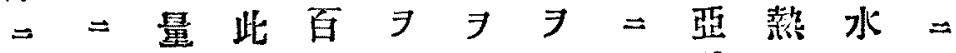
存溜, 度九取取生少硫甘氏

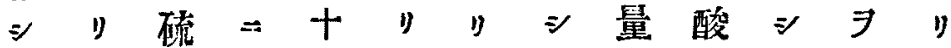
夕夕素於度乾百酸, yメ 几n, $\approx \Rightarrow \neq$ 北類 硫 $q^{n} \Rightarrow \neq$ 其

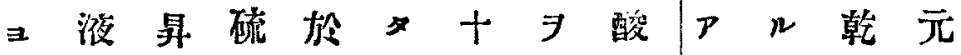

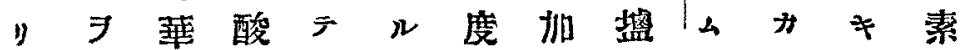

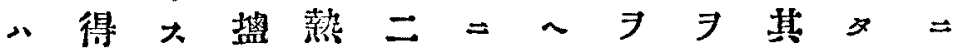
少之n文三酸於合九結必分 $\forall \vee \Rightarrow$ 硫 $>$ 化 $=$ 酸有十果亞解

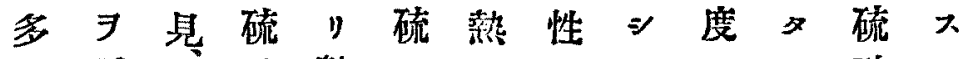

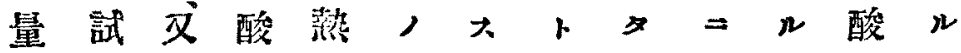

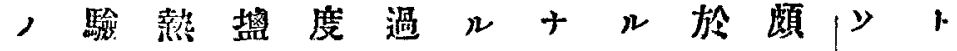

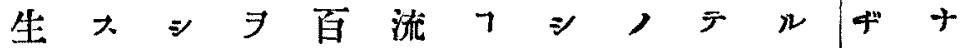

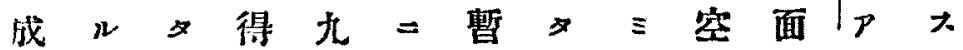


造棏 , 盐酸和飽非

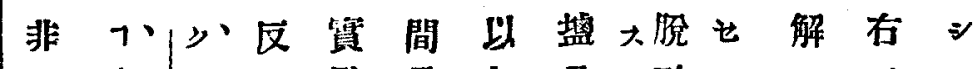

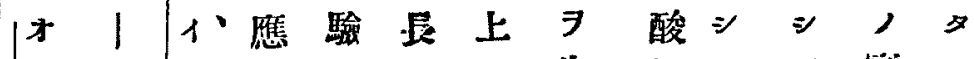

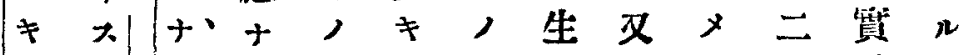

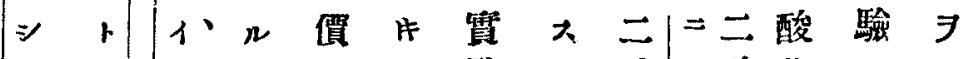

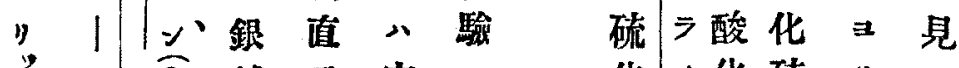

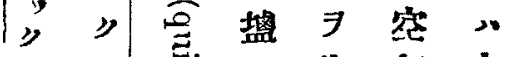
盐 $、$ 志 $=$ 失氣之

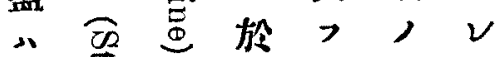
旁 Э、以 1 员作恐用再 $+\stackrel{\square}{-4}$ 用 $v=\equiv$

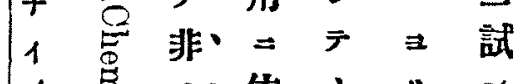

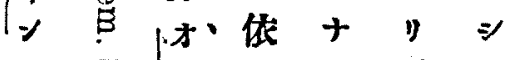

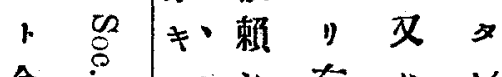
合

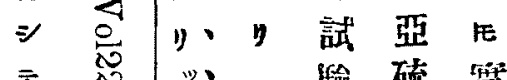
₹ 䖝呵》、中酸 驗 珤、硫盐㭙

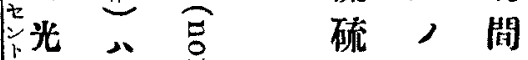
$P$ 類高酸自”

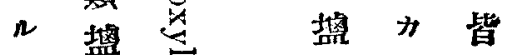

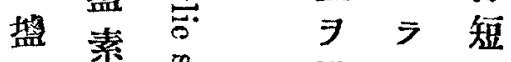
$\exists$ 盐总騟分 成若出解为 * 窇 $ᄏ$ 七 、营區、 $n n \approx$ 川密別 “\#葍 , 又次基雼 ミ八几、殊 メ時 化大化硫り 夕 硫 酸硫艅大り ᄀ 小川 量玫次 $P$ 牛 限 亞品 心

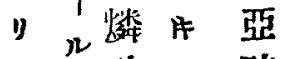
$\boldsymbol{P}$ 留酸心硫 2 橴荊酸

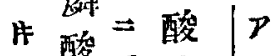
八忙留素 N 分 = 燐 7 学

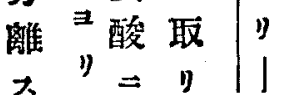

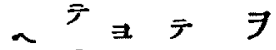
*度り硫 辰 硫㝘的酸㙓

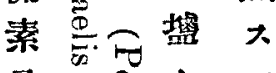
$\exists \cong 卜 v$ 吸志要么 収题”二 三芯硫酸 $\bar{\Xi} \supseteqq$ 素化 硫同 硫三大分 $\exists$ 酸》力離 分
香 突 化 學 露 訫 第 is 帙

Fi $\frac{1}{\pi}$ 


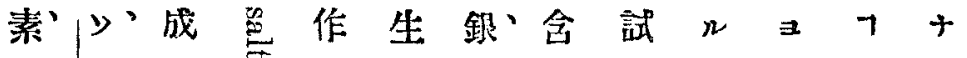

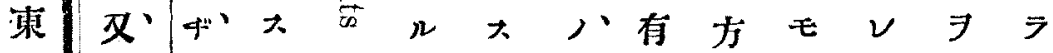
京

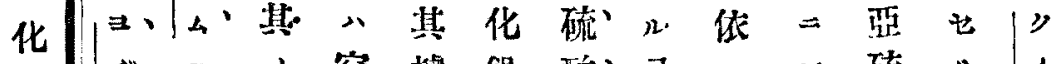

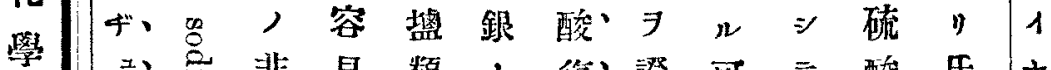

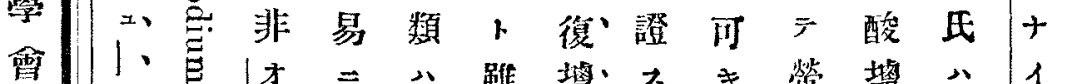
誌 第 共 帙

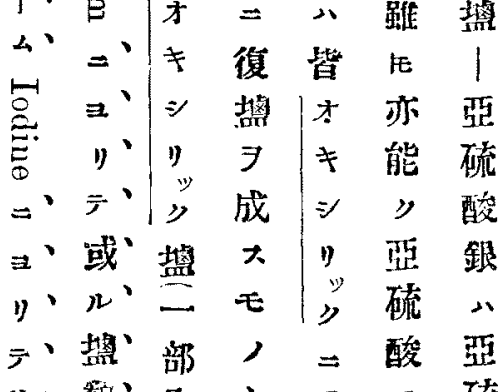
他、賴、分十 $+P$ 硫 八ハール ラ ル 酸

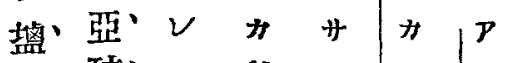
数、硫忐 故 几!り ル 二、酸、右 モ $=$ カ

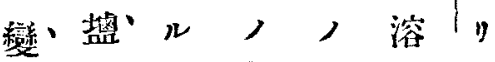
化、 $\Rightarrow$ ’ 如 $\Rightarrow$ 解 $\Rightarrow$ ホ、戀一”限 た 溶

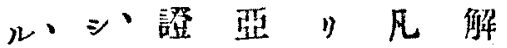
五フ、午十硫類り

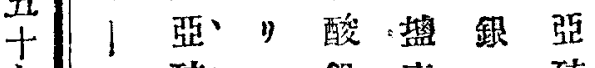
九 硫銀素八硫 兴酸、, 增 其 酸 卜盐徨 復 復

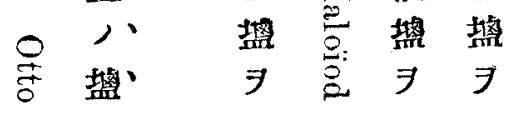

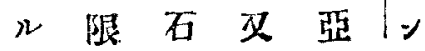
$=$ 光八硫, 足、 $>$ 二酸 19 $n$ 亞 $N$ 酸 盐 キ 硫 モ化 心 シ 酸, 硫之! ” 盐 $=\langle\nu|$ , 投溶 $\exists$ 盐 非入液試, オ $\nu \exists \equiv$ 畓 \# $\Rightarrow$ 其 110 栄光 1) 現 $+=7$ 》将 1 \# 消 堺 今清 隇 消, 水世 二隇硫 氏 部它酸及心 分 $=\Rightarrow$ 予 十山溶, , $\nu$ 故解 留力 E $=\equiv$ 騇 $P$ $\exists$ 此 $\Rightarrow \Rightarrow n$ 
造搆, 坥酸和飽非

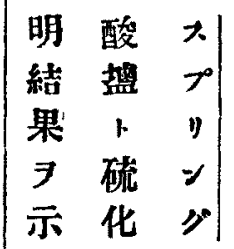

大 盐

E 1 . 䃊

, , 究

+ 混 =

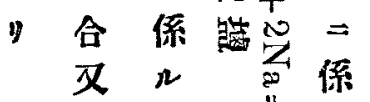

硫坥

硫 化

酸 硫

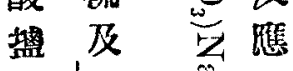

\begin{tabular}{l|l}
1 & $=$ \\
1 & 4 \\
混 & 1 \\
合 & 4
\end{tabular}

$\Rightarrow$,

於 亞

几 硫

反 酸

篡 埇

モ $=$

亦於

同师

一 及

, 亞

證 硫

及

坆

和

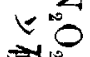
新要

펙

$x+$

$\approx z$ 办

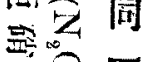

제용

種

䋵

モ

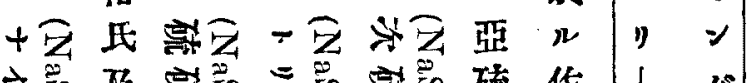

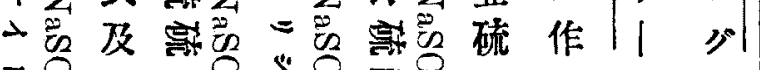
-

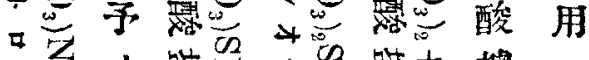

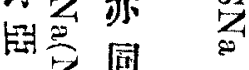




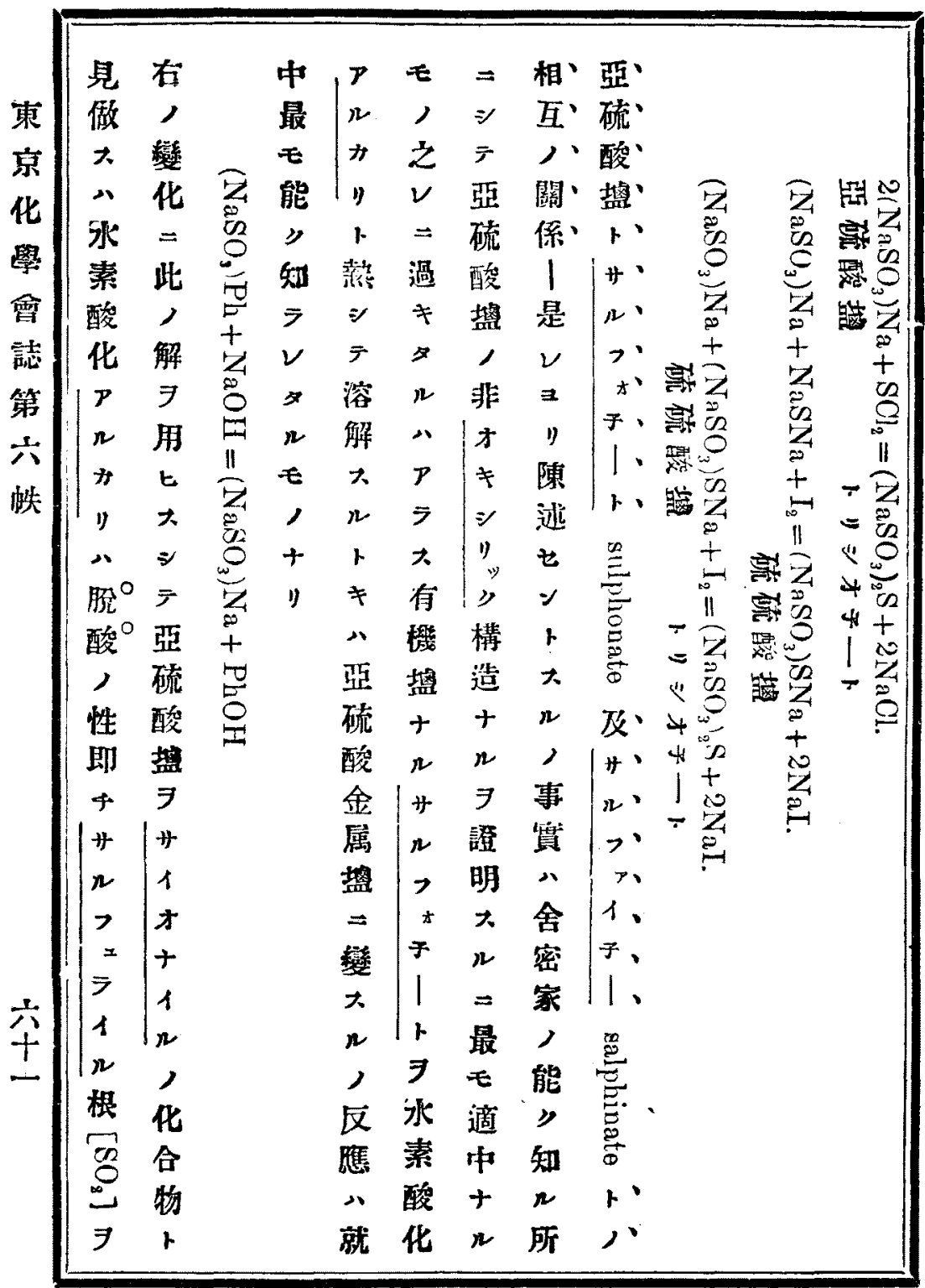


造 構, 㑑 酸 和 栬非

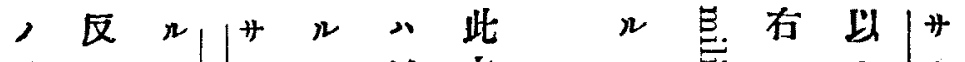

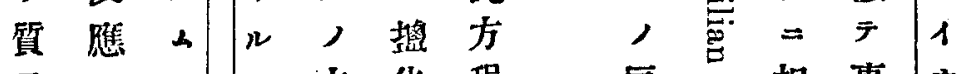

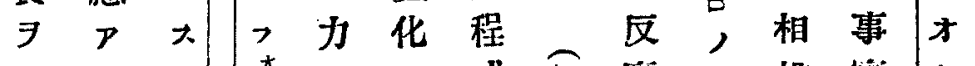

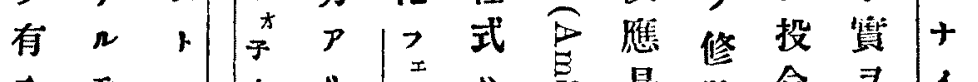

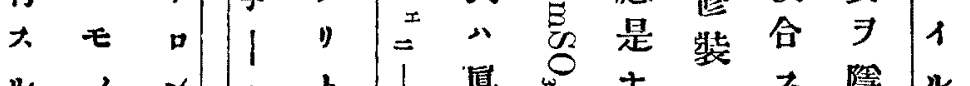
n,

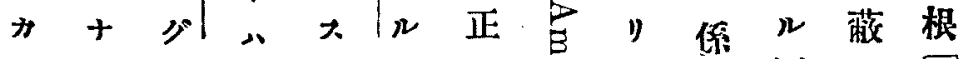

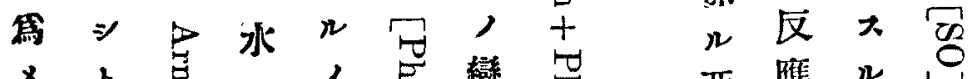

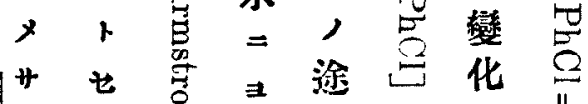

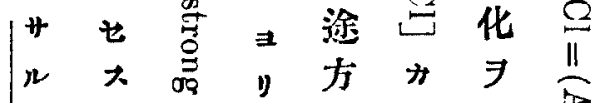

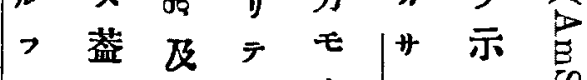
$\pi=\equiv$ 分 $+1 \neq 0$ 子其几解 キ 才 金 $\overline{1}=$ 豫 + , 卜属 1 想 $1 \%$ 同 一原第密 $\exists+$ , 狀 反十, 硫モn妇州 留几镜腔, $\rightarrow$ 得

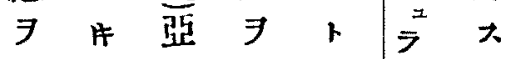
呈 其硫生云 1 或 大酸 酸 ス八ル ッ $n$ 搵盐 $n$ \# = 然

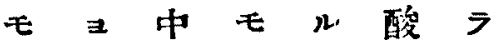
, $y=$, 可化 $+乇 モ+\#$ 七 y難亦

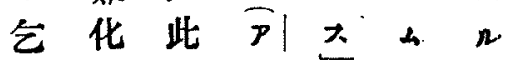

亞應n号 硫 、モ 酸 칙

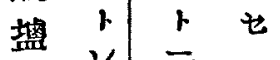
, 偲 $\overline{\text { 云 }}$ 水茫心山 溶 $11 \# n$ 液导州, $=\underset{\mathbb{2}}{\mathbb{N}}$ 可性 $>$ क $\Rightarrow$ 1) 今 有

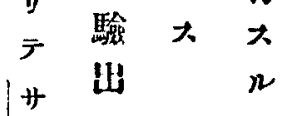
$n=$ E

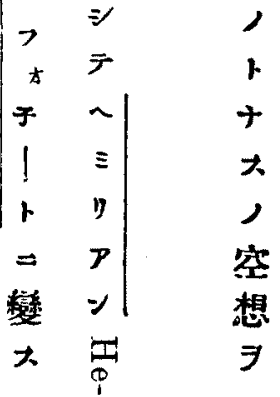

東

京

化

學

霄

誌

第

S

帙 


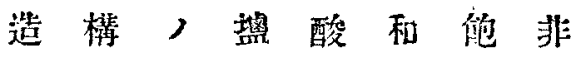

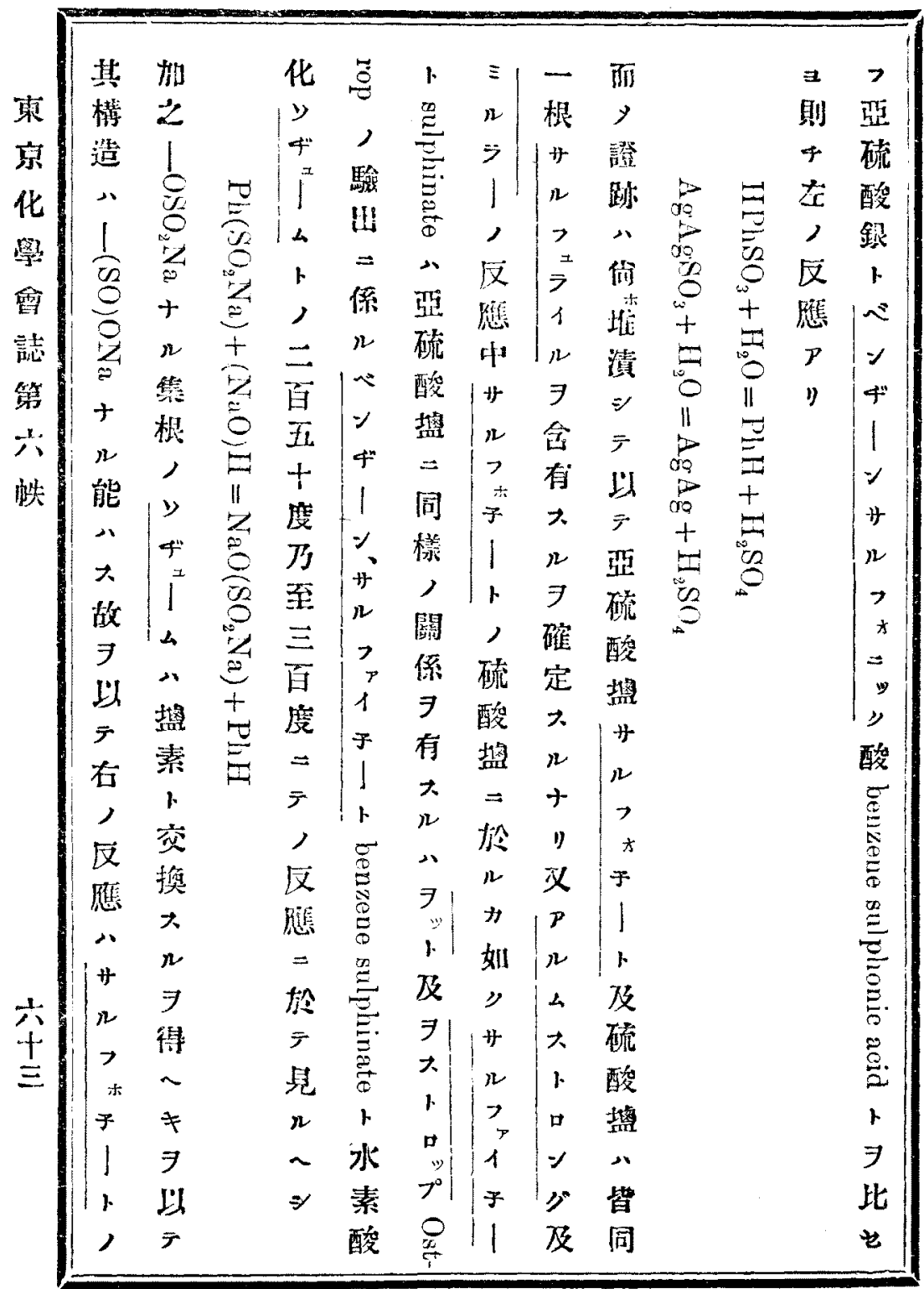


造構, 塭酸和飽非

モ亞造夫 $夫$ 頃 $=$ 一本

, 硫, $、$ 及易入論

十酸異然|サプ|り掅ノ

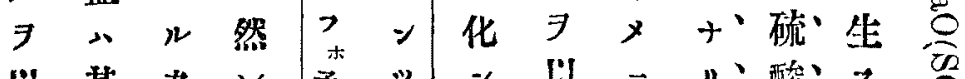

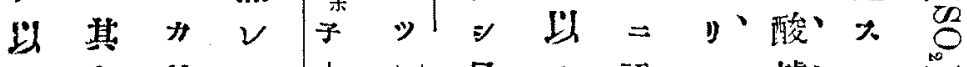

テ金故压|

其属 = 亞卜产市

, 根 $>$ 硫 八, 1 $n$,

硫,

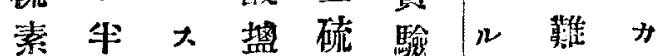

酸

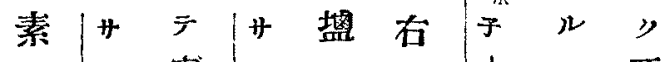

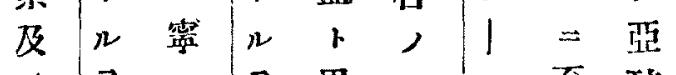

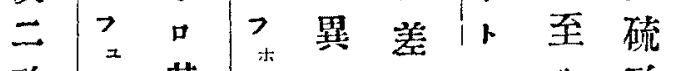

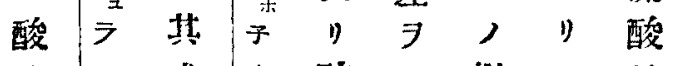

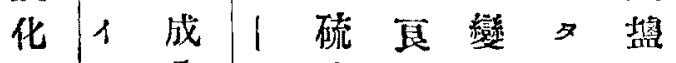

窒化分素大化ル

素, $、 1$.

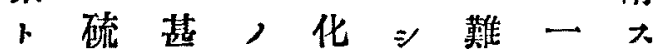

化素》行合》》瑟几

合卜異篇せり酸由 =

三㨁十, \#蓋化 “|”

易接 里異为

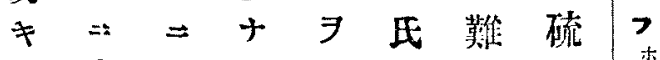

所化因几上, 酸李

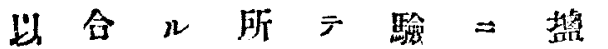

䍂、ル

$1>$

其区十

八留

制 $=7$

合、少 9

ニ、ラ 證

化

學

角

誌

第

枀

胅

酸、サ 明

化、ル

シ小+

易、リ7

₹

川

裝

非

酸、

化、

全、

属，

根、

, $三+$ 以 + 出在,

ᄏ、

念、

七刀 $>$ 》"

佂

\#.

硫

, $n>$ 構 $\geq$ 近化同

粶。

酸

盐

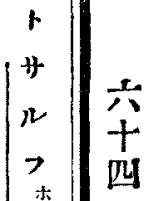


造構, 搵酸和飽非

ル 党

東 カ 党根大 $大$

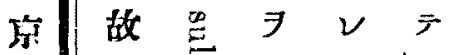

化

學

會

声

第

六

帙

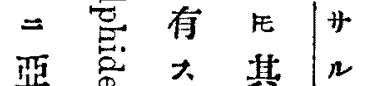

$=$ 有原

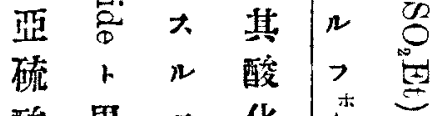

酸

搵"因三十0

$\exists$ 空易 品

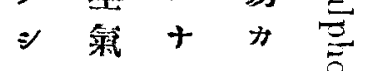

广中

可二又\#,

溶 酸 硫 几 其

硫化化 “㱖

化 $=\left.\right|^{x}$ 之造

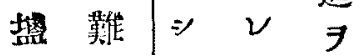

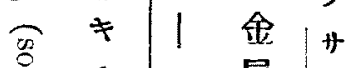

$\stackrel{气}{E}$ モ

志同 导根,

驾琹里, r

至 $=$ 代 1

基基

$=\frac{\vec{\Phi}}{D}=1$

共,+ 第卜

六如》硫三骂

五
ᄏ化营人, 川 插 = 酸硫右抑 入 $>$ 百化素, 此

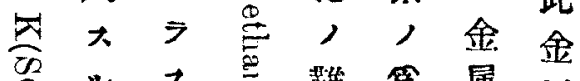
踓第属属 ₹. . 根, 因乤琶二,

$x>$ 由 其地存

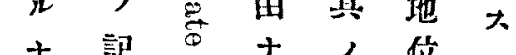

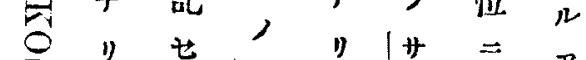

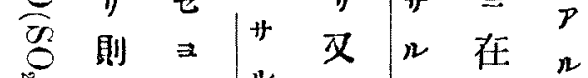
茞是

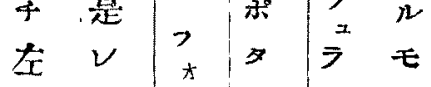

, 人看 如, $1=0$ 心

$\Rightarrow$ 評 1.91 則

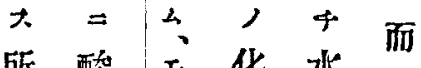
所酸 $x$ 化水 I 化 七合素 金 属几 \%止㟶n 1. \#素,

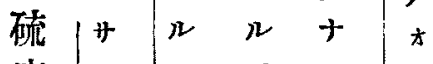
素 $27 \begin{array}{llll}2 & 7 & y & 7\end{array}$ ， ?

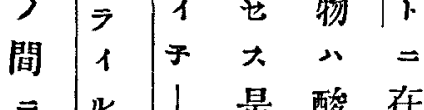
$=1 \boldsymbol{1} \mid-1$ 是酸在 酸,卜人素口 素變 基 刃 


\section{造棓，搵酸和能非}

千盟 金

ノノ属

ㄱ. 7 田り，水斯化溸化

十 變 根

几含 $\Rightarrow$, 存 $\Rightarrow$, 学

り化，

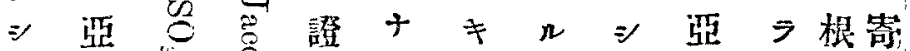

易硫。巨导十酸, \&硫

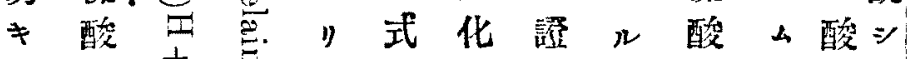

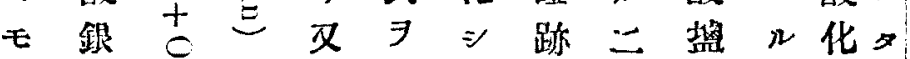

, , II 留严有易 7 酸, 小仧上

八银合一硫大车是化酸夫山カ

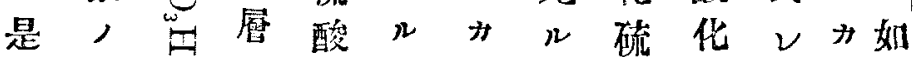
$\nu$ 如 + , 亞故 $㇒$ 中 只故》

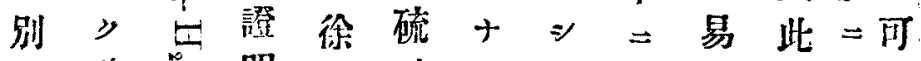
種酸 $○$ 明二酸り蓋小 $、$ ノシ浴 , 化 3 酸

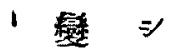

示化變 $レ$ 乾硫以山硫化

化易

$\rightarrow=\geqslant$ 濕 $\neq$ 酸

$=$ \#

モ $=$ \リ

シ $\overline{7}$

\#

朤 n

段モ

$=1$

於十

$=n$

解 牛

說 其

$=$ 亞

硫

, 次

$+$

次

砣

" 酸 以

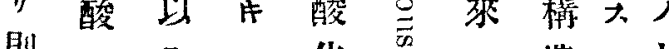

則 $\bar{F}$ 化

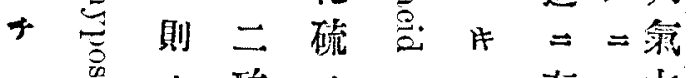

总千酸人

非化酸气潞江,

死酸硫化言氣, 酸

東

京 化 學 角 誌 第

化, $三$ 品 $p$ 化

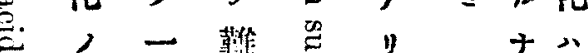

二水分”焉及水

n 酸

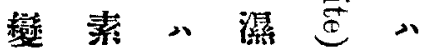

酸 


\section{造 構, 热酸和 飽 非}

以キ然於二度度n, 二硫

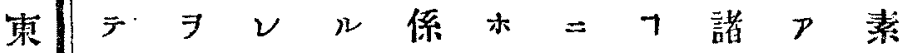

京亞論比作风大, 在八品

化硫 三本用三人, ”

酸併論二酸事

搵已, $\exists$ 化筫存 7 接市.刃六酸”

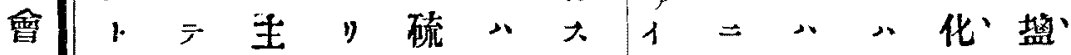

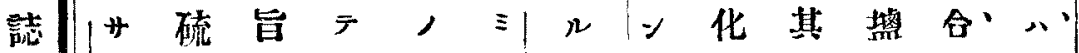
第 $几$ 酸 十盐四》下, 合化素少二 六 $\Rightarrow$ 搵几 蛈子, 亞 \#化》證在》力如有代 \#硫 1 硫入跡大几小キが 酸才盖占二ルA二生的”。

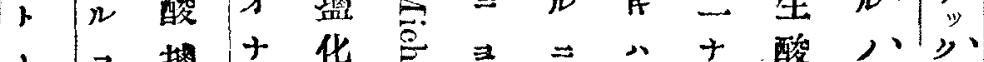
$卜>$ 盐十化 成点

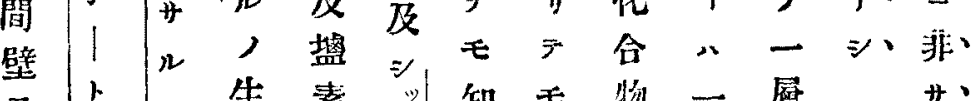
71, 生素州知毛物一層

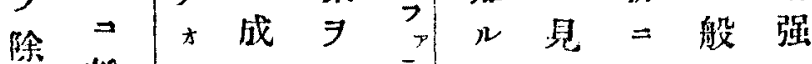

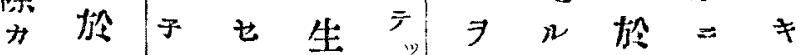
$\therefore \mu \mid 1 \quad n$ 寒 $\#$ 得

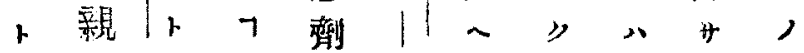
大密卜是 $\Rightarrow$ 石 $三$ 及化 $\nu$ 卜 六 $⿻ 上 丨+$ 投焉之叫合 $\Rightarrow$ 值 十 $3 n$ 構》

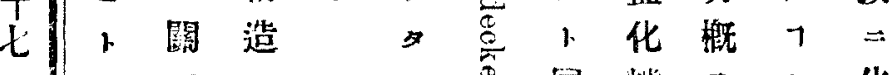
八係, 心空间粼于+化 硫 7 琵无, 結, 皆”合

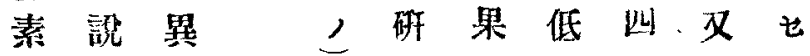
, $\neq+三$ 究 $=$ 温 + 右 $\triangleq$

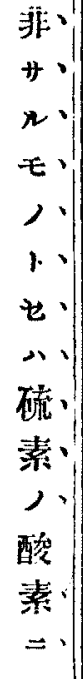




\section{造構，热酸和飽非}

, 人 +++ 種 水數悉化研 息酸 哜 1 . n 1. $+\bar{T}$ 相 七 口 撞 》 1 此 モ) , 如 $\underset{\sigma}{\stackrel{5}{\circ}}$

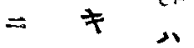

P 物

亏'發

\#存見

$v>=$

此係 其 7 的

存 只

在 硫 酸

大溸化

几 硫

, 四

事 化

$\therefore$ 少

之 $\exists$ n

$\checkmark$ 有 式

$\Rightarrow>\exists$

疑车

$+r \quad t$

$\neq+n$

能 ス モ

”》别年》宸究 蓋 ナ 异問四素ナ

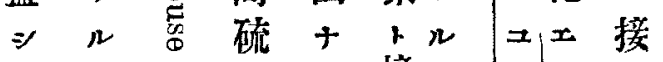

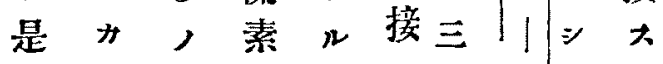

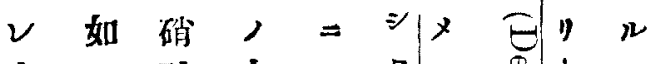

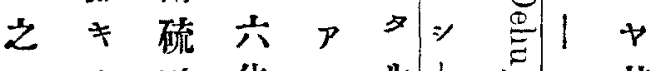
$\nu$ 酸 化 $>$ \% $\Rightarrow$, 盛合 \#丮化导化

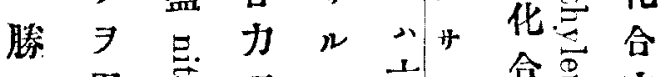
$n$ 用泀 事々 导有

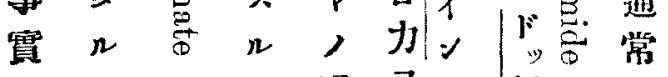
ナ八, モ疑 $尹$ 志代, 仮

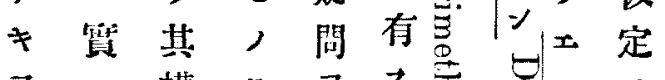

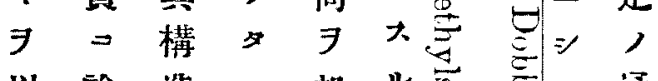

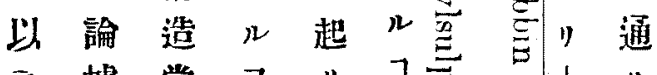

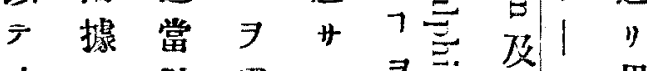
止, 㭙證 $シ 7$ 学 $\mid$ 山弱不九山示公穴及 者分 公硫 得モ明,

\#, = 侧

$n \geqslant \geqslant 1$

$=n \bar{F}$

出知 且

テル恰 ペ

× 可モル $n \neq-11$
力素 如, $=$ 水 素 將, 硫合 $\Rightarrow$ 近化 $P$ 每時物几 $=1+\pi$

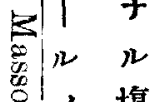

東

京

化

受

霄

誌

第

六

帙

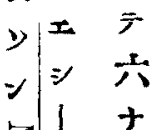
突 
造構, 壘酸和飽非

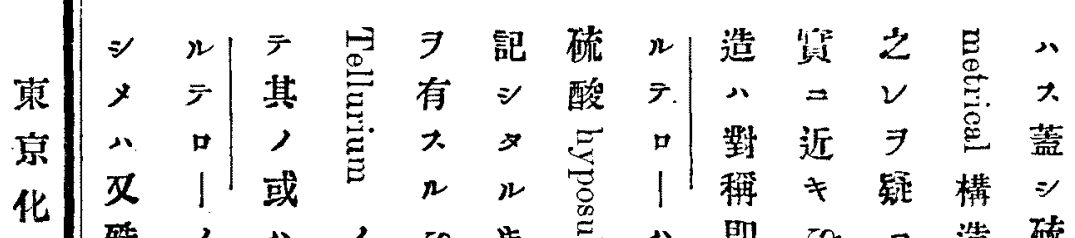

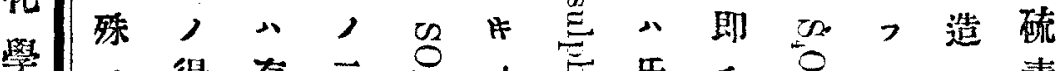

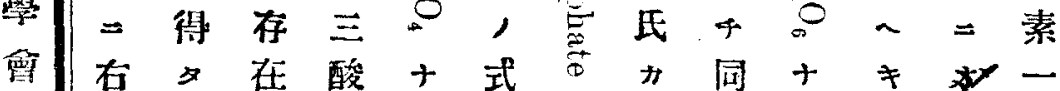

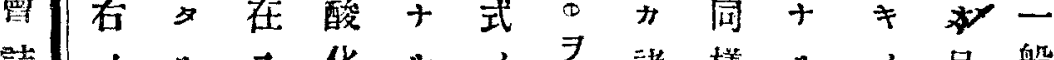
誌, $⿻$ 大化 $n, \exists$ 諎樣n, 且般 第高分 $n$ 硫高一总酸 $=$ 式堽奇, 六酸析, 上酸部员化酸 $尹$ 由数化 快化結證, 化

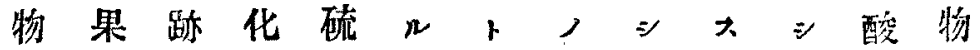
, “十合八, 即式》ルテ素 如若‡物硫三三表几七少原”

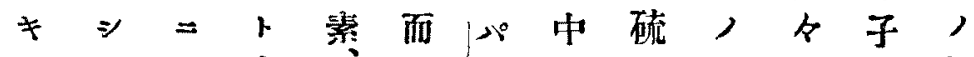
モ氐宜放 $n$ 素〉

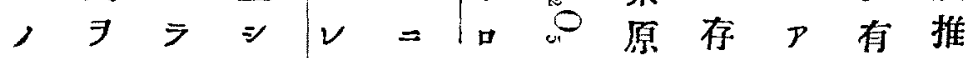
$\exists=\pi \eta=$ 硫亞 脫 酸 其等七山, 酸モ有入而, 性 物精, 峨的一盐, 大八, 简啠

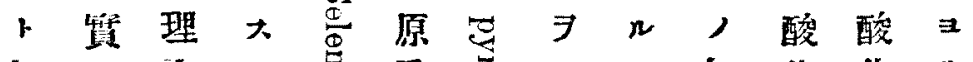
相子由 它子記飞知化化り 共援 $⿻ コ 一 ⿻ 三 丨$ 十七

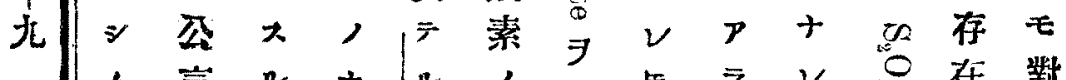
山㝘n+n,

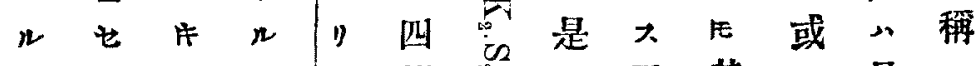
人

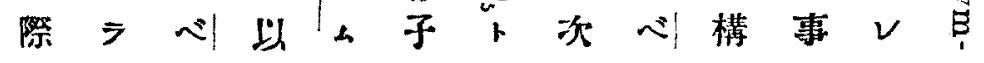




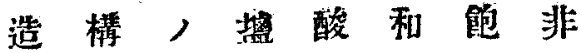

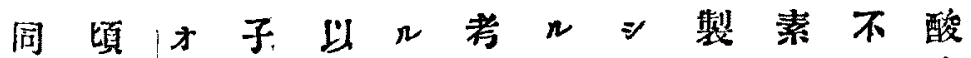
區 ア 》 域 $1 \mid$ 上得雼酸舍决獨几遊 +7

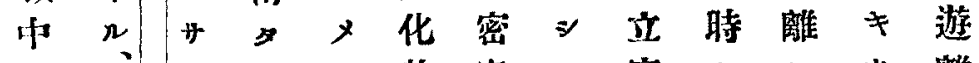

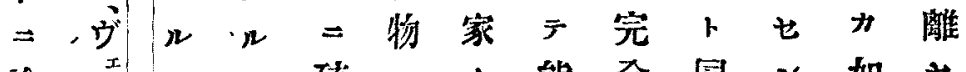
論 バ $>=$ 硫 $、 1$ 能全同 $シ$ 如 大. $\left.1\right|^{x}>$ 素驾云》, へ

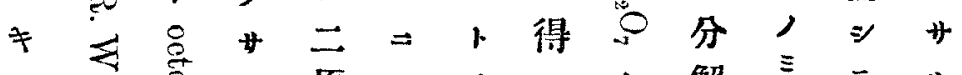

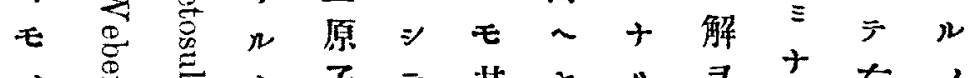

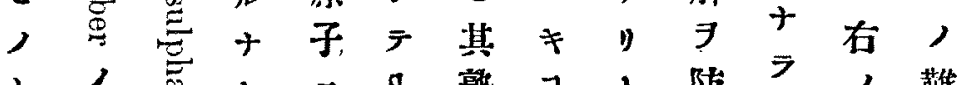
十

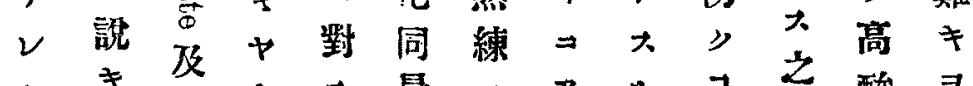
$\therefore \neq$ ○、量 $\Rightarrow P ル \neg 2$ 酸

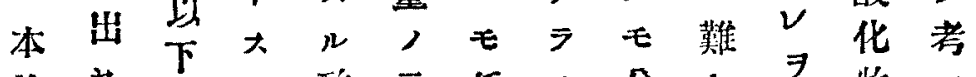
桷也, 几酸三係 二小, 素酸

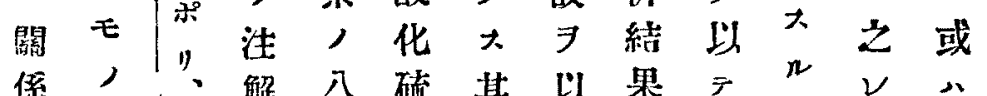

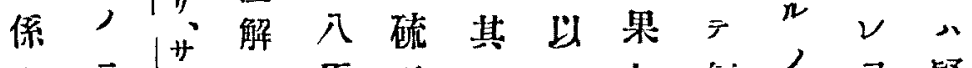

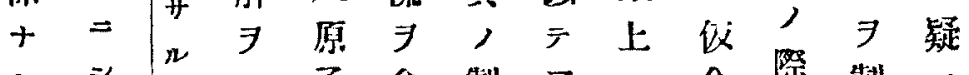
$\neq=\Rightarrow+$ 子含製予 $\Rightarrow$ 合際製

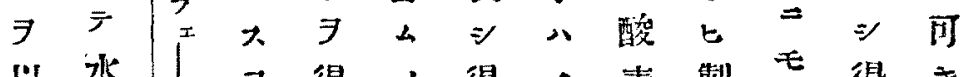
以水、 $\exists$ 得, 得心素製モ得

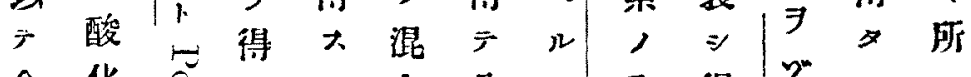
今化总 $y=$ 合分 $=$ 企得 之物异 $三$ 物 析

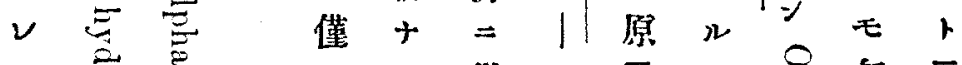

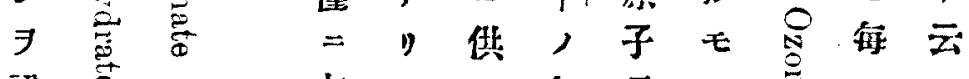

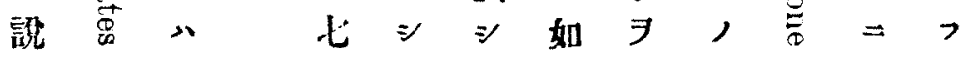
カ1近原 $\ni \Rightarrow \neq$ 見 $\exists \exists$ 酸モ 
造構, 搵酸和鴒非

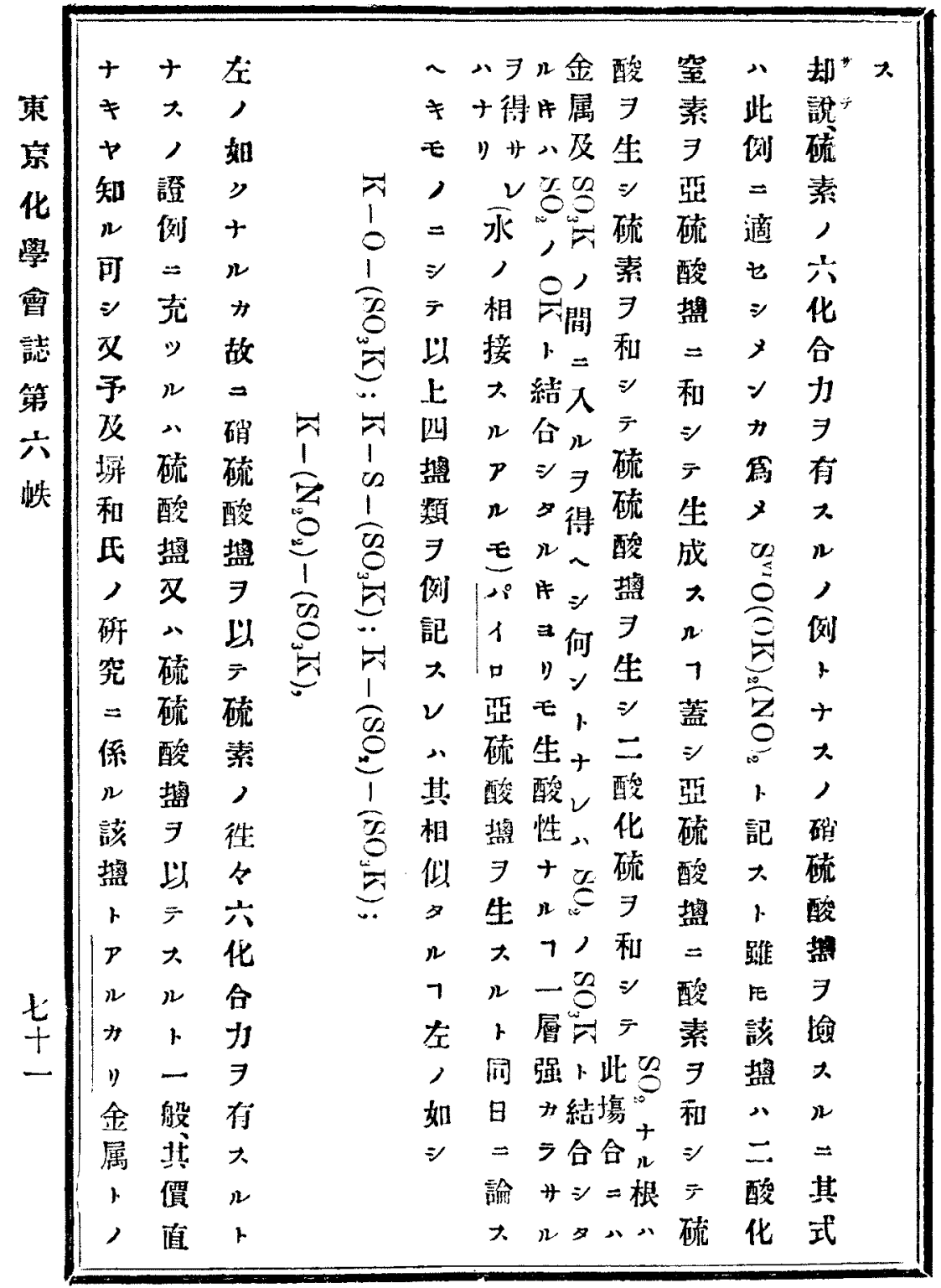




\section{造構, 塯酸和館非}

以, 以九他ト小, 酸 $\Rightarrow$

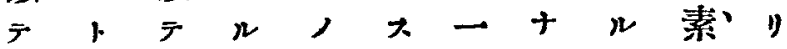

宜定水 川|サ層 $ン$ 如復》

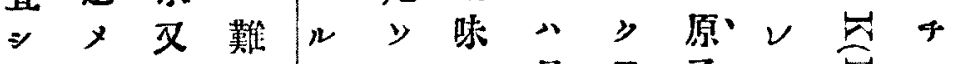

y

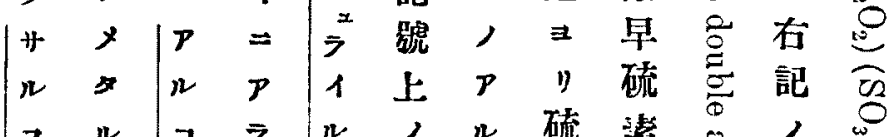

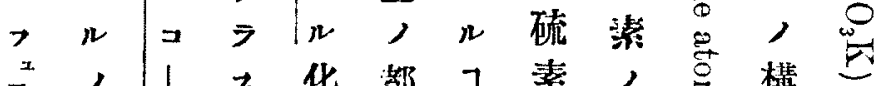

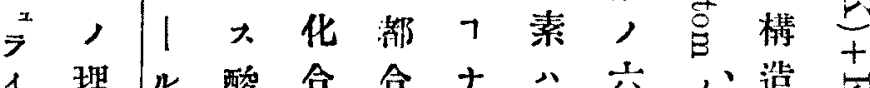

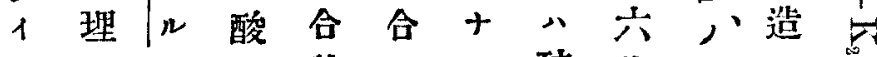

ル由 - 素物,

, 八分小 $=\equiv y$ 酸合合、適

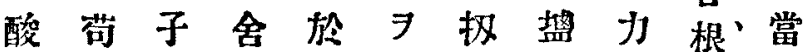

素モ中密テ圖此中

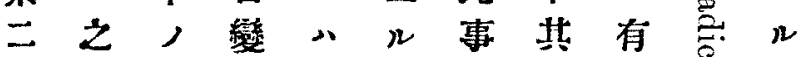

原卜分化叫 $=$ 八化、官七

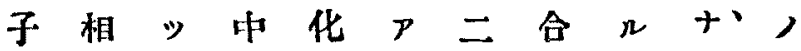

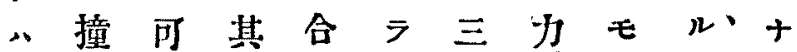

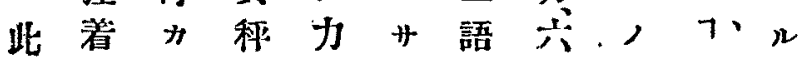

化

合 \#\#八有或以几ル硝知 根

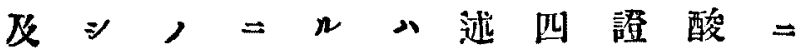
他メ一ア 者硫へ十ナフ搵星

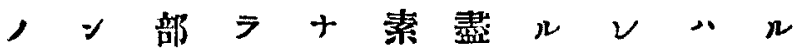

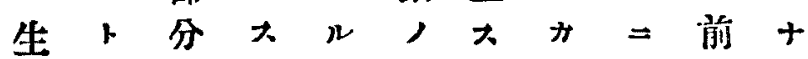
酸 欲 $9+7$ 硫 $\Rightarrow$ 㵋條》 根 $\rightarrow$ 成

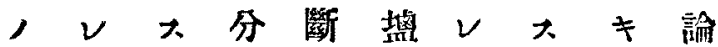
粗 八モ 


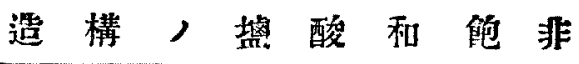

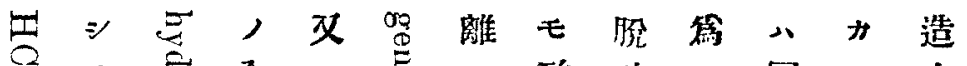

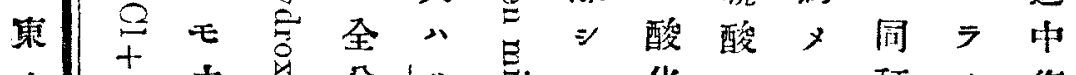

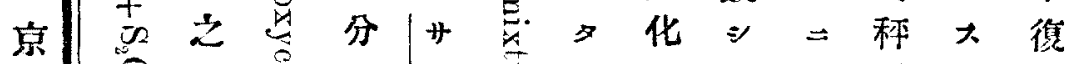

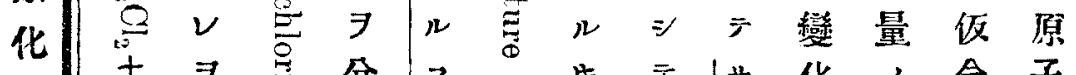

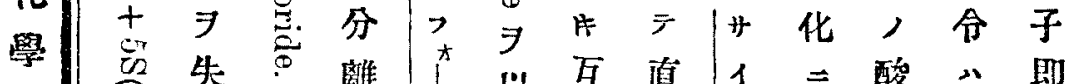

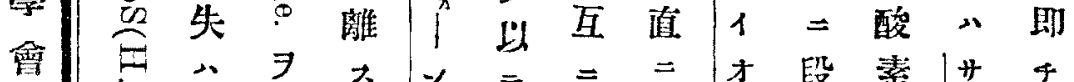
蛙 こ

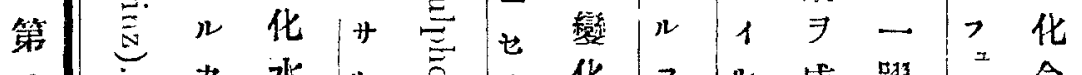

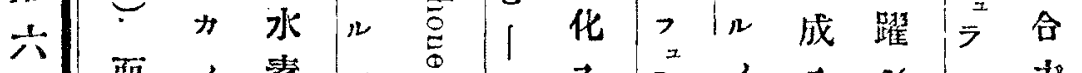
䑨

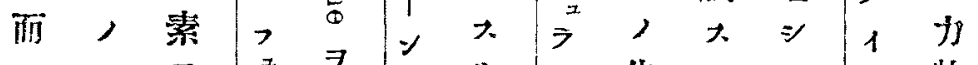

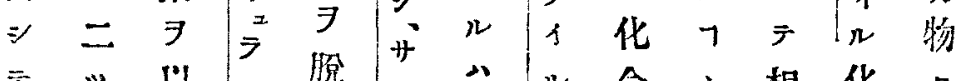

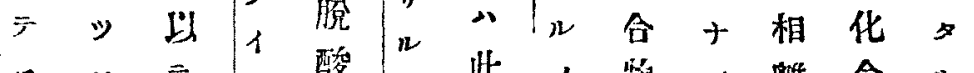

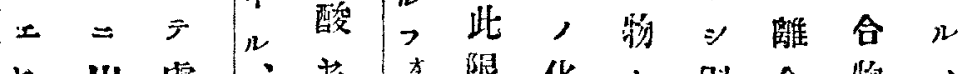

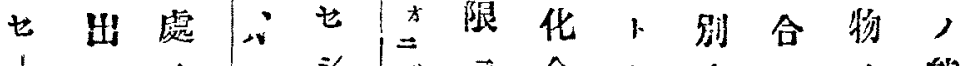

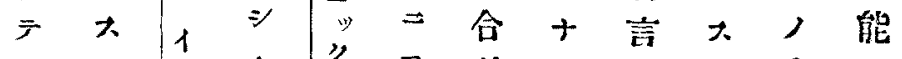
ン 7 『 \# 几 * 其 $\neq$ 八

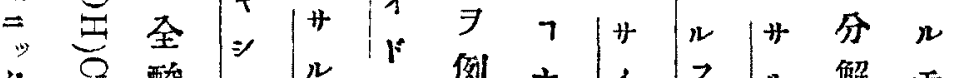
$\because$ 至酸

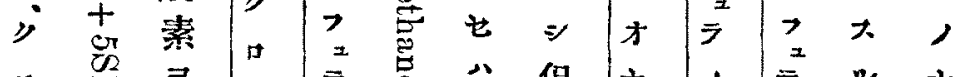

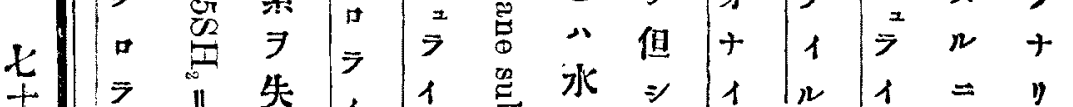

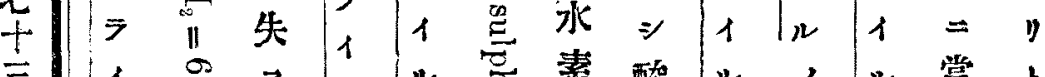

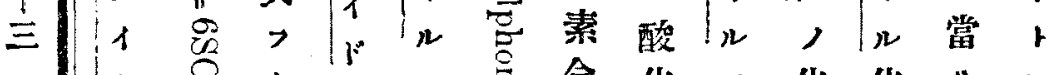

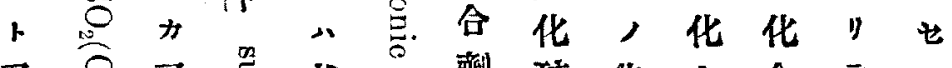
及芭又总其造硫化合合

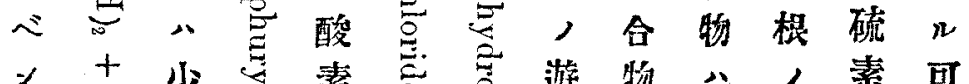
少少素空客遊物入, 素可 


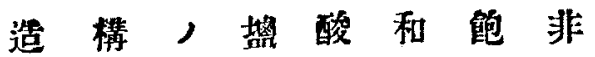

\begin{tabular}{|c|c|c|c|c|c|c|c|c|c|c|c|c|}
\hline \# & * & 酸 & $\mid n$ & $x$ & $\rightarrow$ & 密 & 盢 & 1 & $v$ & $=$ & t & 4 \\
\hline 1 & 1 & 化 & , & $n$ & $\sim$ & 家 & 化 & t & D & 酸 & $t$ & 1 \\
\hline オ & オ & 硫 & 少 & $\mp$ & $\pi$ & ノ & H & + & $\equiv$ & 化 & 1 & $y$ \\
\hline+ & + & 及 & $\Rightarrow$ & $J$ & 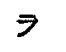 & 䮩 & U & 1 & 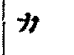 & 硫 & $n$ & サ \\
\hline 1 & 1 & 壘 & $\Rightarrow$ & $t$ & t. & 出 & $7_{z}$ & $\pi$ & $x$ & $r$ & , & $n$ \\
\hline$n$ & 12 & 素 & $\bar{F}$ & $y$ & 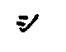 & せ & $\bar{\gamma}$ & $\Rightarrow$ & $\eta$ & Ii & 生 & ${ }_{x}$ \\
\hline , & $\Rightarrow$ & 1 & 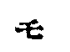 & 是 & $\bar{\gamma}$ & $n$ & 1 & 蘩 & 13 & 盐 & 7 & $=$ \\
\hline \# & 變 & $t$ & 生 & 等 & 熜 & 所 & IN & $\Rightarrow$ & $\therefore$ & 化 & $n$ & " \\
\hline$\pi$ & $x$ & $\eta$ & 7 & $\Rightarrow$ & 素 & $=$ & $\mathscr{W}_{0}$ & H & 盐 & 燐 & 7 & 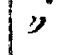 \\
\hline 7 & $n$ & 亞 & $n$ & $y$ & 及 & 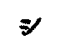 & 0 & 7 & 化 & $r$ & 八 & D \\
\hline$\overline{7}$ & + & $\vec{\gamma}$ & 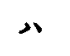 & 考 & $=$ & $\bar{\gamma}$ & $\underline{2}$ & $\boldsymbol{7}$ & H & $J$ & 前 & $\overline{7}$ \\
\hline 1 & $\eta$ & $=1$ & 初 & $\nu$ & 酸 & 又 & $\exists$ & 驗 & 22 & 反 & 條 & 1 \\
\hline$n$ & 1 & $\stackrel{w}{7}$ & $\not$ & М & 化 & 塭 & 分 & 出 & 7 & 雔 & $\mathrm{e}$ & $F$ \\
\hline$\Rightarrow$ & $\bar{z}$ & to & 盐 & 嶺 & 硫 & 化 & 解 & セ & $\overline{3}$ & $\Rightarrow$ & $=$ & $\exists$ \\
\hline 酸 & 八 & E. & 化 & 化 & $\underline{\exists}$ & | & 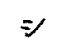 & y & 1 & $\nexists$ & $z$ & $\eta$ \\
\hline 化 & $\#$ & , & \# & \# & 而j & $n$ & $\bar{z}$ & 2 & n & $\nu$ & $\nu$ & 五 \\
\hline 七 & $n$ & 定 & $n$ & $n$ & $\equiv$ & 7 & 二 & $\overline{z_{i}}$ & 川 & $n$ & $\exists$ & 盐 \\
\hline$\#$ & $\exists$ & 反 & 7 & 7 & $\overline{\bar{\gamma}}$ & $\bar{j}$ & 酸 & $\sim$ & 五 & $モ$ & 論 & 化 \\
\hline$n$ & 得 & 礁 & $\bar{\gamma}$ & $\bar{F}$ & 盐 & 1 & 化 & 1) & 葳 & ' & $\ddot{z}$ & 燐 \\
\hline 7 & $\pi$ & $\Rightarrow$ & 1 & 1 & 化 & $n$ & 硫 & 然 & 化 & + & $\Rightarrow$ & J \\
\hline , & & $\boldsymbol{z}$ & $n$ & 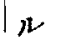 & $\#$ & $\leadsto$ & 底 & $\eta$ & 政粦 & ) & $n$ & 作 \\
\hline 所 & & y & ノ & $\boldsymbol{z}$ & 1 & 五 & 盟 & 耐 & $=$ & 然 & 如 & 用 \\
\hline 誥 & & $\vec{\gamma}$ & 自 & y & オ & 搵 & 䒺 & 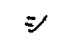 & $\nexists$ & $\nu$ & $\eta$ & $\Rightarrow$ \\
\hline , & & 二 & $\#$ & 罴 & + & 化 & $r$ & $\bar{F}$ & $y$ & 任 & z & $\nexists$ \\
\hline 內 & & 酸 & 今 & 化 & 1 & 燐 & + & $F_{i}$ & $F$ & $=$ & $v$ & ") \\
\hline$=$ & & 化 & 分 & \# & n & $=$ & 大 & 箩 & 徐 & $\equiv$ & 因 & $\bar{\gamma}$ \\
\hline 諭 & & 硫 & 解 & 1 & $\exists$ & $\mathfrak{z}$ & 7 & 化 & $=$ & , & テ & 堝 \\
\hline 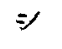 & & ' & $\approx$ & オ & 得 & ) & 21 & 燐 & 盛 & 書 & 生 & 化 \\
\hline$\Rightarrow$ & & 临 & $\bar{\gamma}$ & + & $\pi$ & $\bar{\gamma}$ & 右 & $\therefore$ & 化 & $=$ & 大 & \# \\
\hline$\rightarrow$ & & 化 & $=$ & 1 & 生 & 製 & 舍 & 酸 & サ & $\exists$ & $x$ & 1 \\
\hline
\end{tabular}




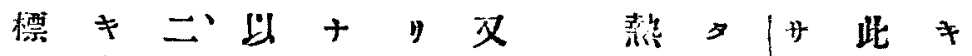

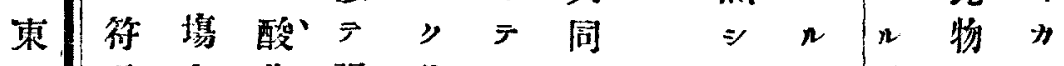
京 $\exists$ 合 化强 先 二 $三 \quad \Rightarrow-7$, 如 化用 $\Rightarrow$ 硫厂 テ 酸》

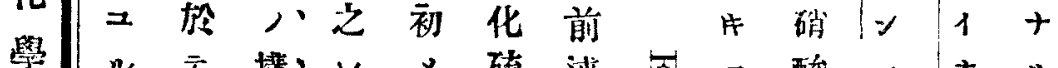
會

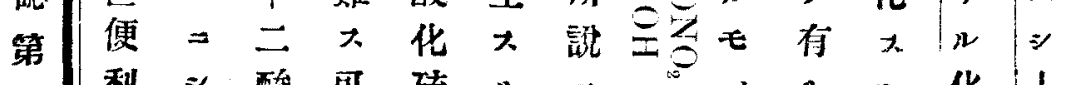
六 利 $\approx$ 酸 可硫 $n= \pm, n$, 帙大テ化

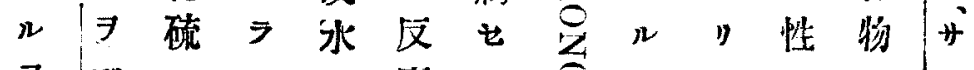

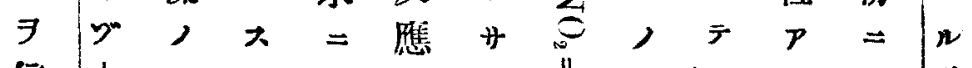

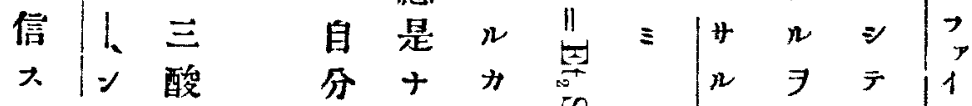
伋 ○化 合 $\triangle$ 硫

入或 㘘

垈式

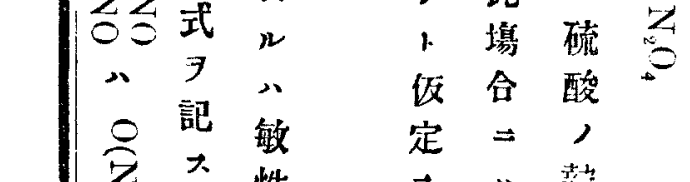

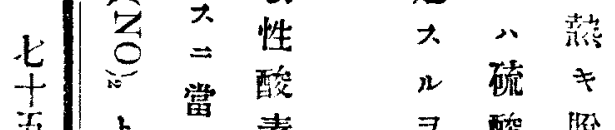

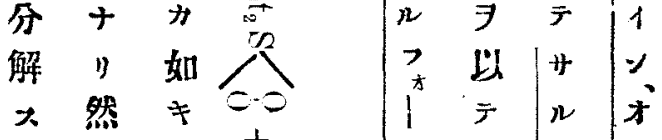
N $v$ モ

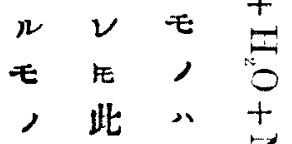

1. 管 硫先

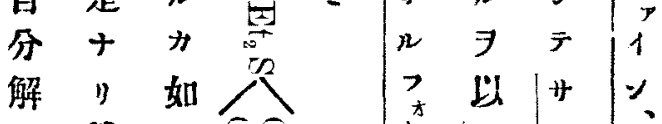
7 酸 院 得八酸 記 $=$, 七 $\triangle$ 生 几 疑 劑 r. 7 . $\neq$ = モ $\curvearrowright$ $\ni$ †

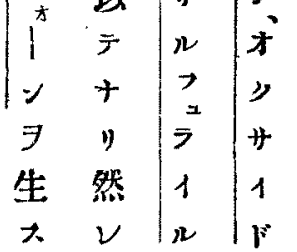
比化里 八此合导 此 酸 物 总 物化士总 卜物ル畐 确 $=1$ 员. 酸 $八=\frac{0}{0}$ 1制1十 $\Rightarrow$ 然氺 
造橉，盟酸西䭂非

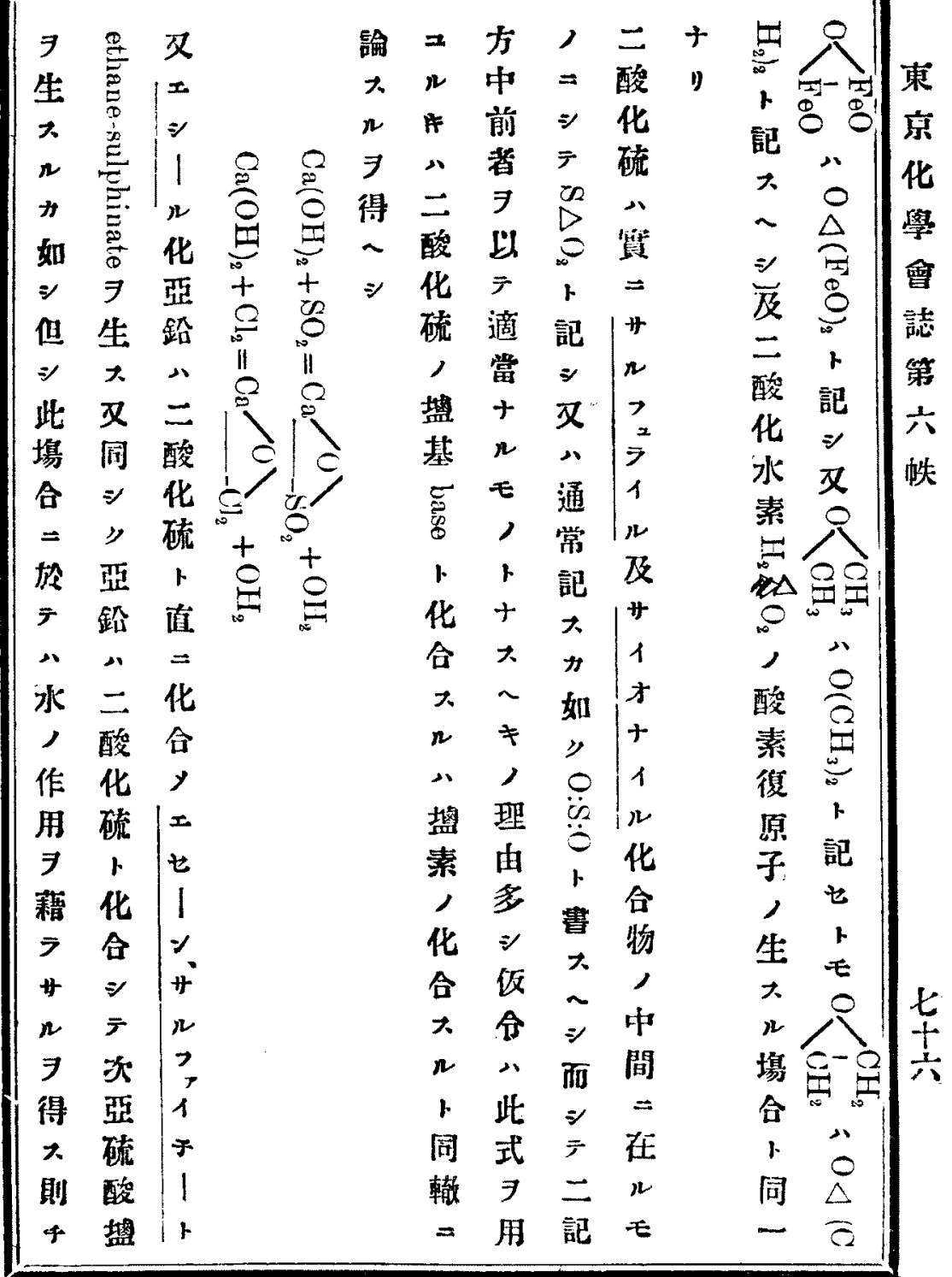


造構，搵酸和飽非

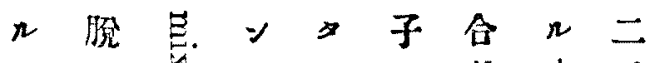

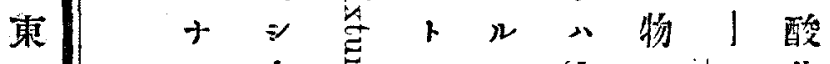

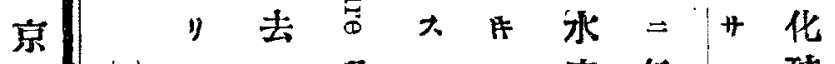

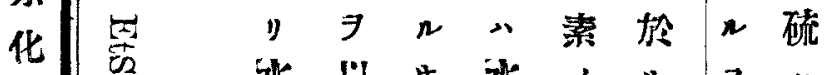

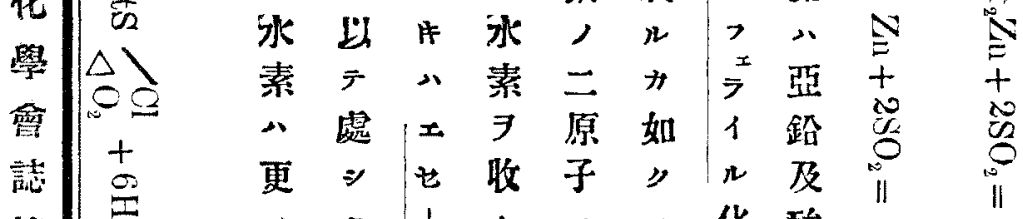

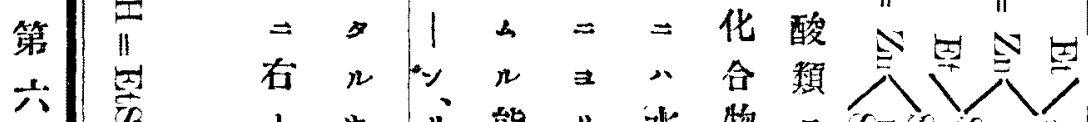

帙

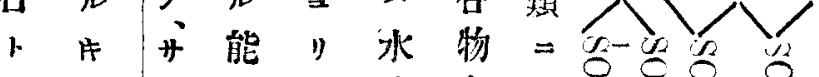

同, $⿻$ 几

時 如 ᄀ \#铇

$=\geqslant \triangleq \nu$ 和 以 酸 テ

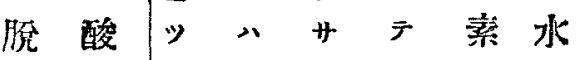

溸り+レ代復素

，；； $；$ 原化

$n$ 二喏止 $シ$ 硫

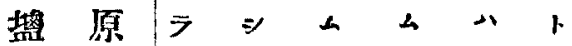

素子|1 强

, $\mid r=$ 以能 12

地水 $\boldsymbol{7}$ 此 $\approx \cdots \mid 卜 丿$

位素氷變 其 $大$ 口

习卜素化, 之 $\neq$

占 艾合 $\exists$ 他 $v=0$

山代暂起根䂭几心

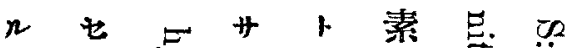

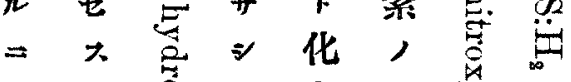

止 $\approx \underset{0}{\circ}$ 合

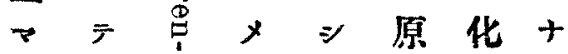




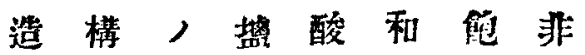

合卜 = 分分一做今 然然

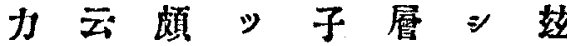

$+>n \sim$, 固 $テ=$

ル吅其 カ放 $>$ 一酸亞口他

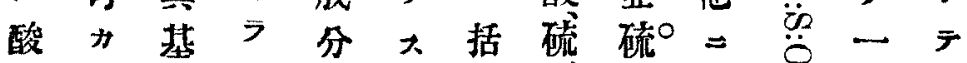

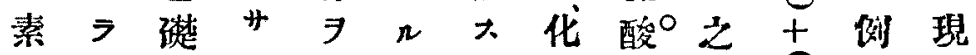

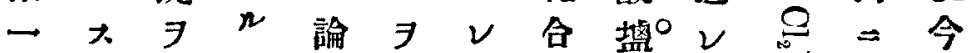
原仮弱无，見小特|=於， 子命 $>>n$ 严 7 其類

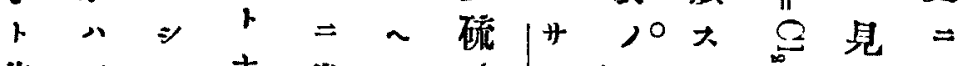

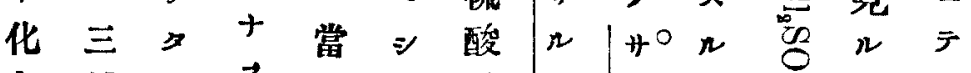

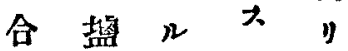
$\Rightarrow$ 化 $\rightarrow$ \% 五䗲如考復 盟, , 按襍 化 一 + “根 燐 化 $\nu$ 化 8 及合毕合要 酸 其少吾

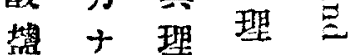
化水諭节

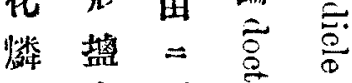
7. 素 至 生 二 入 原 $\overline{2} \stackrel{8}{\circ}$ 几子几意子 “文克亭卜 懒 分, 同 素二十再栐

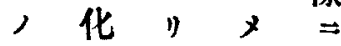
萮 $\rightarrow$, $\Rightarrow=t \quad t$ F $\bar{\nabla}>0, \quad 0$ 二 $1 \bar{j}^{\circ}+\Omega$

酸 才 $11^{\circ}=$ 化 $\neq$ 渞 $\mid$ ル。 $=\quad=$ 化 1) * 合 ” 1 物 $=\pi$ 中० $P+>0$ $>1$ 地。 万、估。

r 相 $+\quad$

ㅈ. 化 , 合 兒 物 确 㩐 热 F

$\stackrel{9}{0}$ ト If. \# $=$ 入 解 $\Rightarrow$ 其

東 宛 化 學

雪 詰 第 $\frac{1}{1}$ 帙 


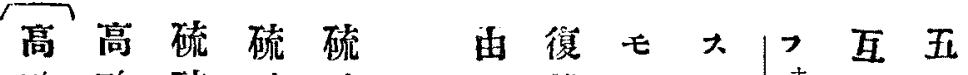
東 酸 酸硫酸 酸

京 化 化酸,

硫 硫, 酸

若若高化化 ${ }^{\circ}$

學

佥

誌

吃化至要 $>0$

第 ++ 化化 10 卜

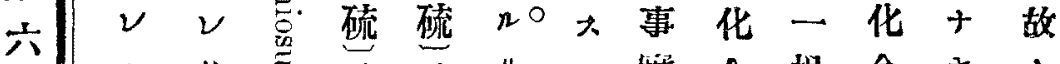
跌

苍凝 酉

○縮 斯 $\mathrm{O}$

$\approx$ 体, 0

产 $z+$ 化 $^{\circ}$

$\approx$ モ 物 ${ }^{\circ}$

算 合根合 $\neq$ 卜

相少物 $\ni \approx$

互琵暮中不

, 論宫, 問他

關 7 蒡 $-=7$

係 シ 高 = 措 顦

$\exists \overline{\bar{\gamma}} \Rightarrow \bar{z} \equiv$

或

,

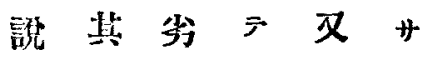

明勢 三召酸几

大カサ盐山

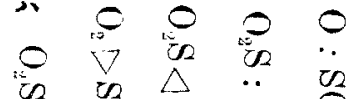

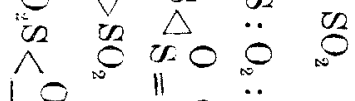

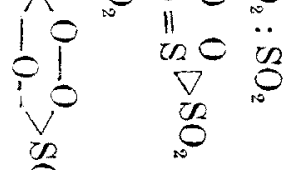

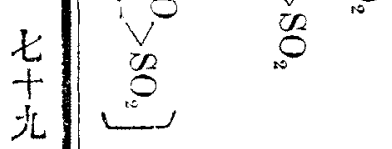

n $7 n>$ 化之 能失モ李耀 “川, 1 ”右

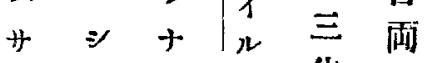
n\&, 、化物 モ $\cdots$ 化合, , $\Rightarrow$ 䫏合力性 $>$ 足 三 物 根質 $x \pi+\left.7\right|_{x}=$ $\Rightarrow$ 八成|类, 
造楆，貔酸和䭂非

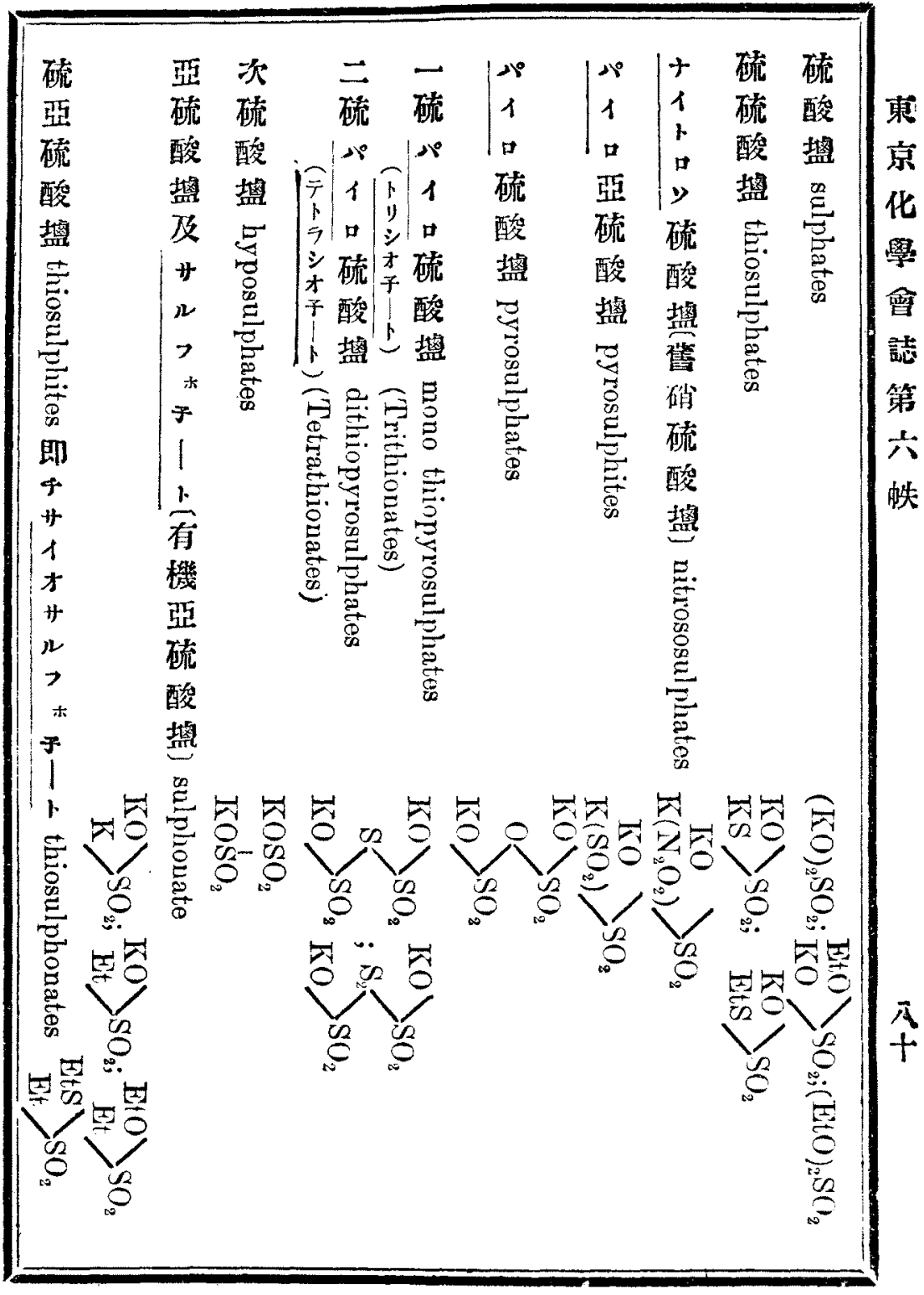




\section{造棈, 临酸和鸰非}

ノカッ 硫

東 ナ可 モ 酸

京

化

學

會

誌

第

六

帙.

八 》入属

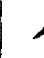

如 $\approx$ 硡

力壂卜

₹ $>+$
习凝、苏次 有 如 縮”丝

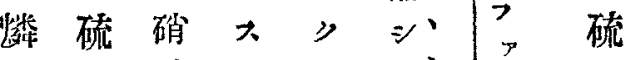
右 異 $=$ 水 酸 酸 酸 几

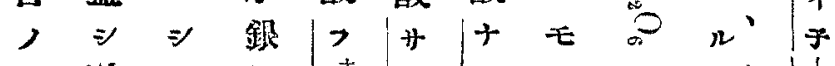
区 硫 $テ$ 銅

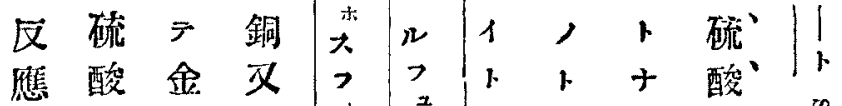

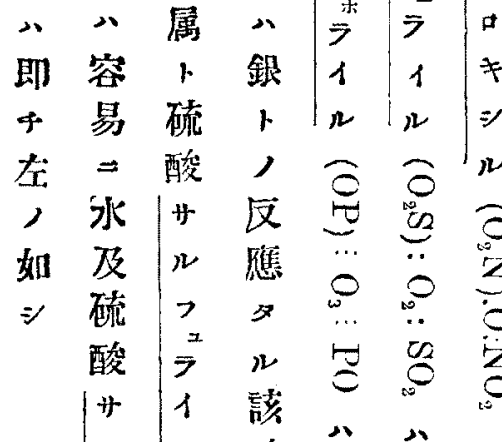

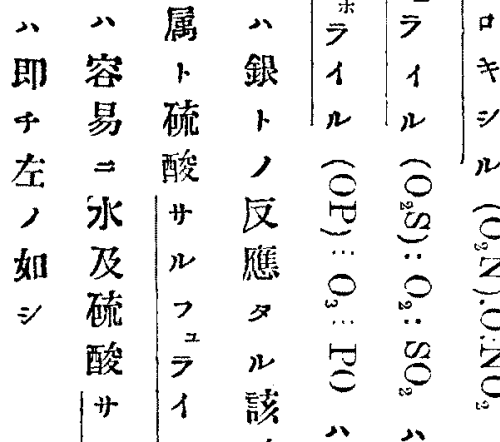

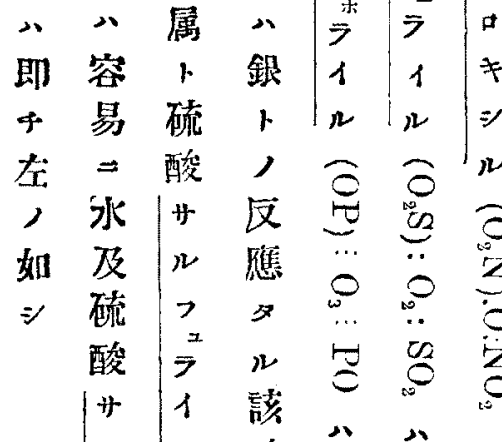

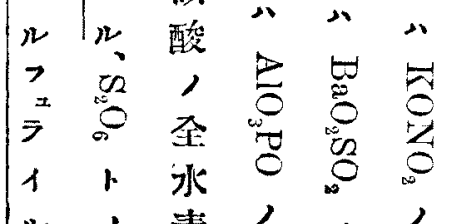

二間染如如如成其

自二水

分止品

解 モ

7. , 分

几1. 離

モ大
= 類 $工$

至卜”

ル同

則 -

\& , 定

轠

造 8 
造構, 堺酸和能非

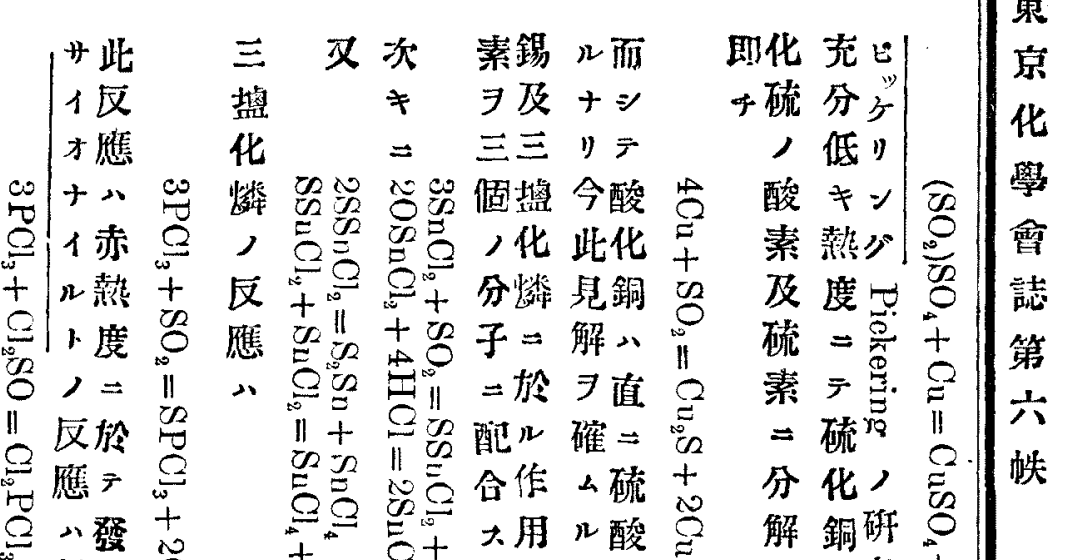

+低大筑

唯ル齿

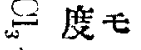

$+\Rightarrow 1$

旅生

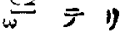

大然

$\bar{z}^{2}$

可比

壈

焉化

$+=\frac{E}{S+}$

品 +0

点要

大用几酸

八力銅

同篇卜

一x+

$\Rightarrow-\eta$

$\approx$ 例硫

厂 化

二㦛銅

酸ンモ

化 =高

硫二涇

八酸度

三化二

分 硫於

$\Rightarrow ノ=$

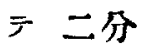

其热解

原化大
シ 究 +

両得二今

物 $\approx \geq$

各 + w

銅り二

1. 此硫

化 生酸

合成,

万、八銅

n 予=

$=$ 以於

因 $\overline{2}$

乙 之作

り $\nu$ 用

+ $\exists \equiv$

+ 三”

7. 酸 
人热, 硫、

東|トシ造硫有心酸望弱总,

京見・棈酸、大、素

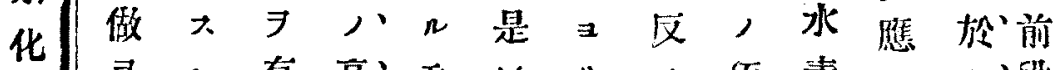

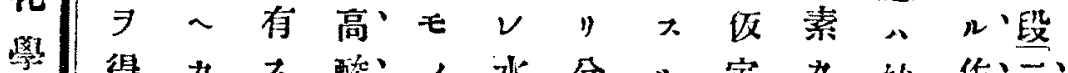

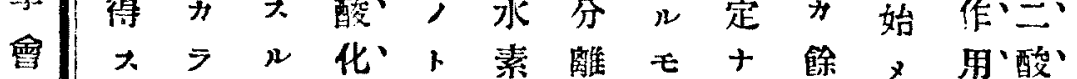

誌、大 モ 硫、七 $、$ 、

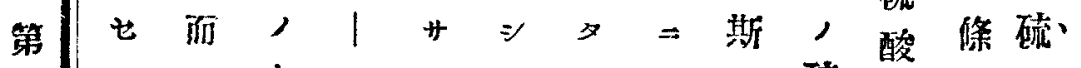

六

帙 未

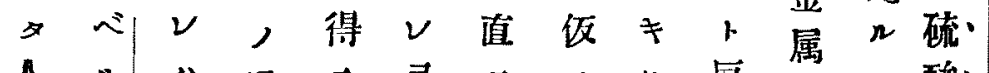

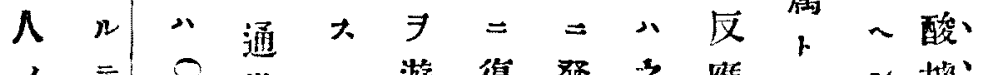
年省

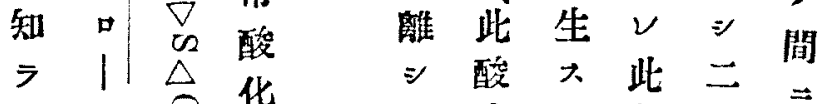
\#, 0 化

高+硫

モ 酸 $\pi \quad \exists$

, 化 粠 $三$

$\Rightarrow$ 物 造 テ

1 八,

然 此高

八”物 酸 及

＼cjkstart素 $n$ 類 酸 据

上下

，化，金硫 汉

金合上属 7 之

属大+, 生 之

$\exists n$ 大 水大

リモモ素ルさ

七, 此 $\exists+$ 因

大卜兆發》”

+ 而 $\Rightarrow$ 化 0

流物 合

有, 它

十見素生卜

做

它存 +

舍》

n $2 n$

密如テn根心

$n ! モ n$ 式

力》斯，據生 


\section{造 構 八盛酸和䭂非}

硫害前 ル 式 $ッ$ 物高、

硫》段 $\exists$ 八 モ 酸、n已證以, 盐 $+\Rightarrow$ 七 $\bar{r}+$ 硫十相四山並

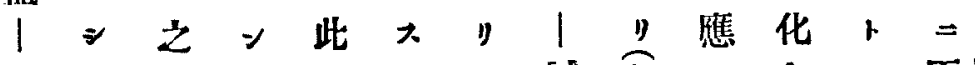
亞 $\nu \pi, n+$ 試@大合, 下 硫 $\ni$ 雼如, 大 $=\varrho$ 力化瀨

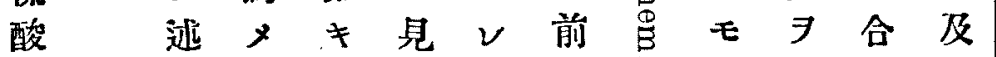
䕘马設成解八記欧, 有物予

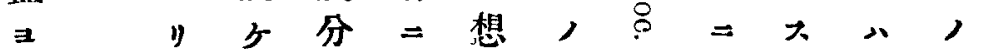
1) 且 7 乘像表

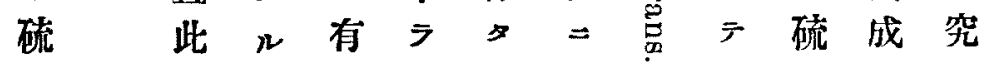
硫式, 大 , $n$ 揭

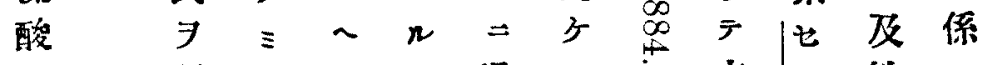

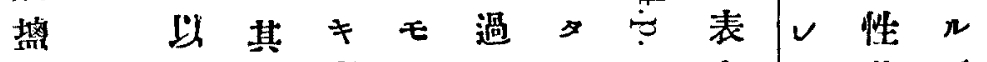
, $=$ 式高, $\neq n$ 总中 $=$ 狀三

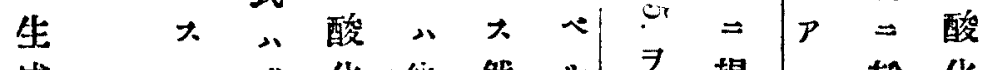
成 $\backsim$ 或化他然

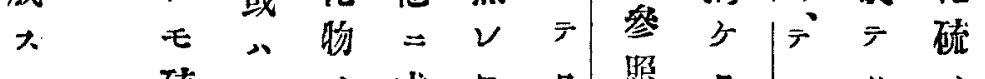

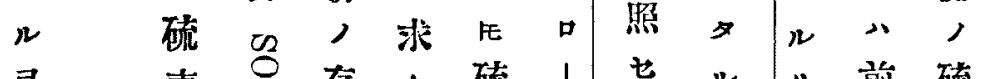
ヨ素○存山硫 1 七㧧

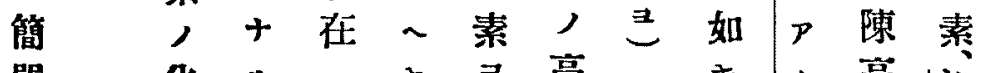
單 化n八 $=$ 合 $=$ 疑 $\div$ 四酸酸等酸 $\nu$

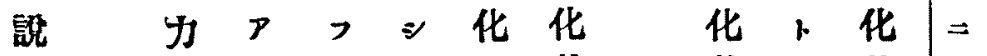

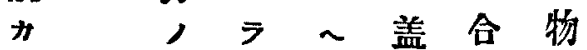

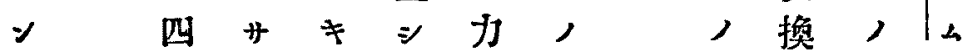

卜. $\quad \approx$ 此 7 式 大、 $カ$, 等有、 物交物西 分 素 $=$ $=$ 八, ス 該 復 $三$ 酸 並 子 $n-1 ;$ 京 化 學 會 誌 第 六 帙 
造構，盐酸和脃非

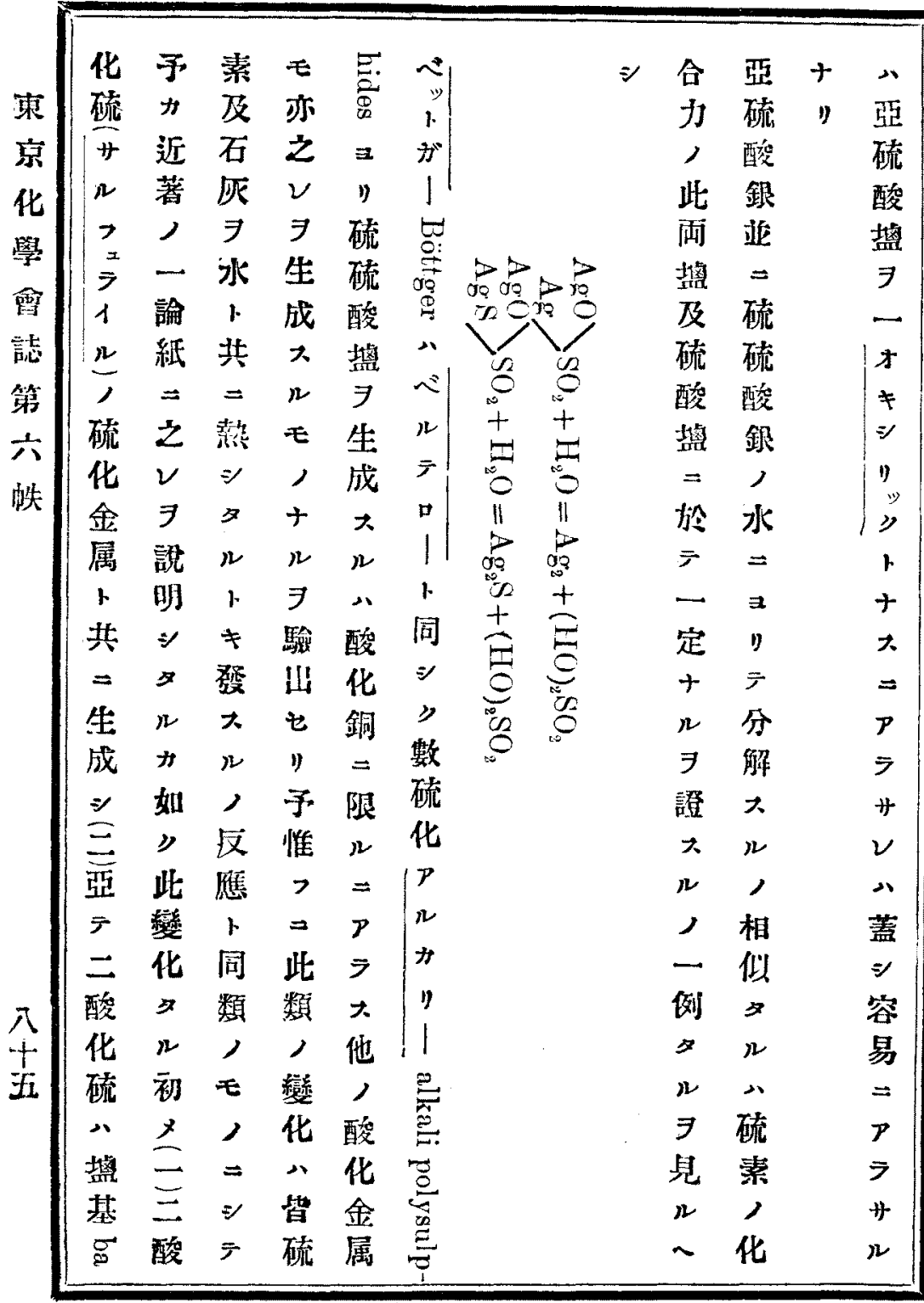


世素け、及

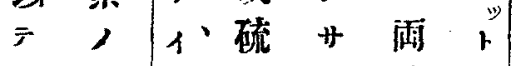

少化 卜酸几硫架

亞合口盐，化１

硝物以、證物

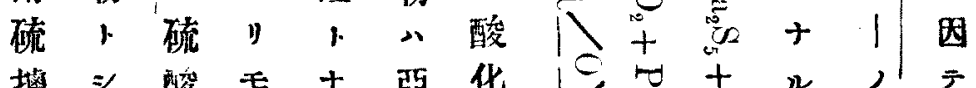

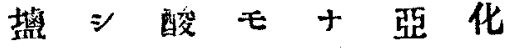

, テ盐容せ硫鉛

條前窘易》酸,

二段 确 $=$ 然搵叫

到二硫還》及硫

”於酸却, 硫化

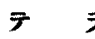

詳 之 热

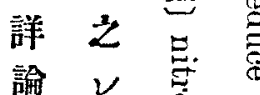

ㅋ 总 $大$ 結 酸 化

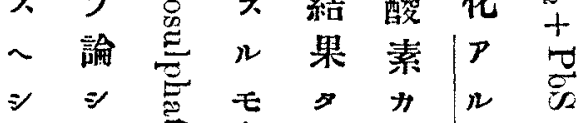

$\Rightarrow$ 密; $⿻$ 硫

１》僅素”

及 此 $x=11$

室堪 $尹$ 数交二

素類證硫代於

, > 化 $=\pi$

化 輩 $x$ 物 g作

合 造 $=$, 用

物 “足亞モ結

+ 巳 $几$ 硫, 果

$n=$, 酸 $=$ 习

习硫三盐》以
八則 8

左程

三三三

如 $\quad$ 学合 $s^{\circ}=$

因 テ 空研成 $\Rightarrow$ 究 $n$

係产 六

酸 硫 化 酸 鉛 城 永,

酸 硫 化 硫 叒酸 五 留 硫 = 化 轉 $\mid \begin{array}{ll}n & \text { 化 } \\ 4 & \pi \\ I^{z} & n\end{array}$ ᄀ $>$ r 区十 憵 ” 


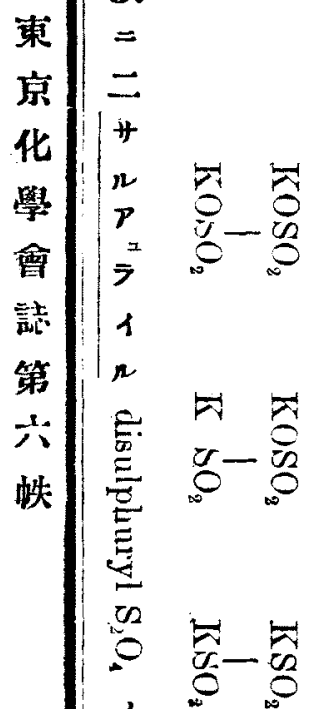

高

酸

化

金

属

r

化

卆
, 故 $1 \overrightarrow{\vec{B}}$ 分 前

如 $= \pm$, 記過

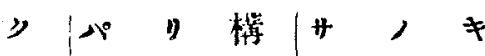

$=1 \%$ 造川表 \#洂

品進說 $\overrightarrow{7}=x$

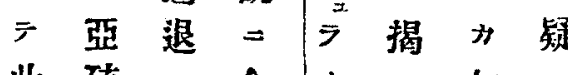

此硫 7 . 合 1 \% 如

盐酸n>nn

類 盐モモ根市

习, , 上 如

$=$ 構 ++ , ,

厂造 $几$ ”間|゚゙

㳄 $=$ 云 $=1$

硫、故酸有

酸 硫 = 化大亞

漗素此硫n硫

及”告”モ酸

次金合化, 盐

亞属三合, 。

硫 = 於茫

酸直 $\bar{y} n$

盐接モ心川+

， 大亦每热 $n$

中心恐 = 水一

間 フラ|サ酸 集

$=T 力 n$ 盐 $\Rightarrow$

位的” ? 要金

七 然方泀属

$\Rightarrow \quad 0=1 \%$,

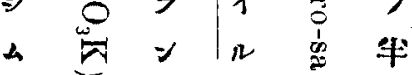

,

$\Rightarrow$ 唓

$>$ 駼

$\Rightarrow \quad \exists \quad$

$\bar{\nabla} \frac{\bar{E}}{\bar{c}}$

皆

我即

$1=4$

口酸

亞㛗n

硫韭 衫

酸硫三

壇酸们

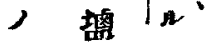

絬 硫

晶 酸

水 点盐

$\exists$ ह

含 离

A

七 其

, 存它

夕在 它 
造棒，搵酸和䭂非

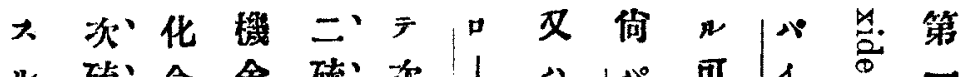
几 硫合 舍 硫次 |

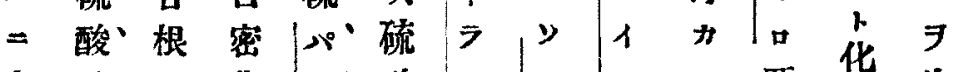
本塩 +學

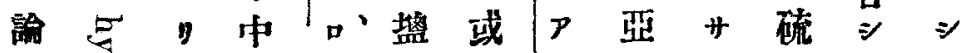
中号二硫二小硫、唒夋 $テ$ 金

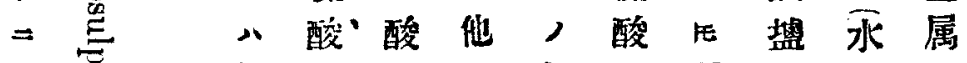

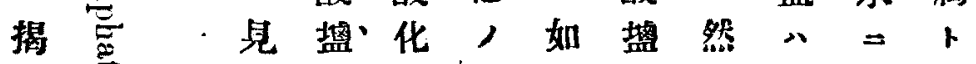
万 $\overrightarrow{0}$ 上卜 女

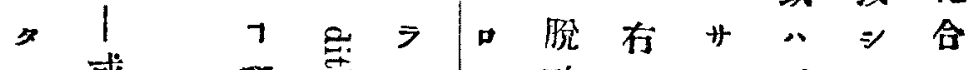

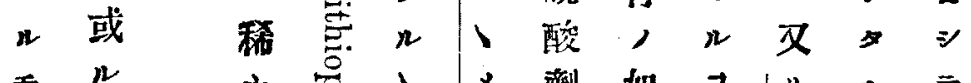
モ $n$ , 舍

1 密

羁家

$+\quad \cdots$

ル

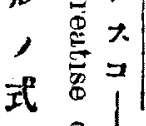

$\exists$ 㝵及

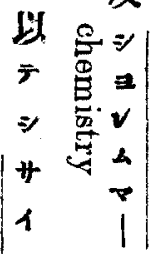

オ此 + वृद्य

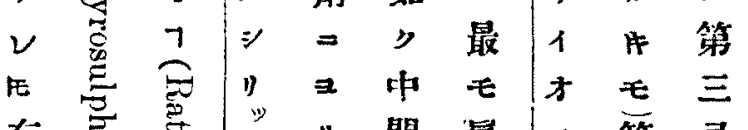

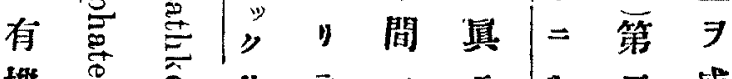
機 蛋焉. 化 $\bar{F}=n$ 二成 三1等合次位近硫 +7 硫此 ‘物亞 化搵事五硫nラ搵分如

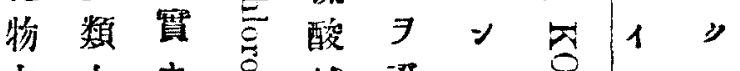
中中十搵證 $\Rightarrow, \quad \stackrel{0}{E}$,

八硫㐫 + -

制素犎

墙

慗

然,

且 復

原

子

$+\cdots$

n 無

酸 》

化 之

密鉛 $v$

$=$ 又

$z$ 八 亞

附
東 通 化 學 畣 言点 第 $\frac{1}{1}$ 帿 $\cos _{1}$ 硫 一 $\frac{1}{3}$ 䤀 酸 盐 化 或然金 士成属 $>\quad 5$ 十而章 モ $=$ 音 知 $\bar{\Xi}$ 
造構, 盐酸和能非

\begin{tabular}{|c|c|c|c|c|c|c|c|c|c|c|c|c|}
\hline 1 & $\tau$ & $\exists$ & $\bar{\gamma}$ & $F$ & \# & $\rightarrow$ & $\Rightarrow$ & 次 & \% & u & ? & 化 \\
\hline$n$ & , & オ & 兄 & 宜 & $n$ & 却 & ${ }^{*}$ & 硫 & モ & $\sim$ & 断 & 合 \\
\hline 根 & $\boldsymbol{F}$ & $\vec{\partial}_{y}$ & $n$ & $\Rightarrow$ & 7 & $\bar{\tau}$ & 筑 & 酸 & $z$ & $\Rightarrow$ & 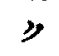 & 物 \\
\hline 中 & 有 & $1 \%$ & $\sim$ & 》 & ${ }_{1}^{P}$ & 舊 & $\bar{D}$ & 錮 & $\vec{v}$ & 且 & 高 & $n$ \\
\hline$\Rightarrow$ & t. & 監 & $z$ & 用 & 1 & 名 & $\stackrel{\bigcirc}{4}$ & $\therefore$ & $p$ & 此 & 酸 & 其 \\
\hline 存 & $x$ & $\therefore$ & & $z$ & 匭 & $\therefore$ & $\vec{E}$ & 又 & $n$ & 盐 & 化 & 做 \\
\hline$\rightarrow$ & , & 皆 & & $\sim$ & 硫 & 1 & $\stackrel{\Xi}{ }$ & $1 x$ & $\exists$ & 類 & \# & せ \\
\hline$u$ & 鹽 & 三 & & $\mp$ & 酸 & ג' & $\begin{array}{l}0 \\
\ddot{Z}\end{array}$ & 1 & 兒 & , & $\Rightarrow$ & N \\
\hline , & 類 & \% & & $\tau$ & 罴 & \# & $\underset{\vec{m}}{\tilde{F}}$ & $\Rightarrow$ & 7 & 經 & $n$ & 7 \\
\hline 外 & P. & , & & , & $\widetilde{\not k}$ & 2 & 1 & t & & 歷 & 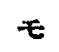 & $\bar{F}$ \\
\hline 他 & 桡 & $1+$ & & $\Rightarrow$ & | & 7 & , & 7 & & 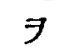 & , & 0 \\
\hline$=$ & 7. & u & & 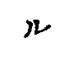 & 1 & $1^{x}$ & 關 & 1 & & 按 & $P$ & 8 \\
\hline 硫 & $\sim$ & 7 & & 7 & 足 & $\stackrel{1}{2}$ & 䋆 & 1. & & X. & $y$ & $\approx$ \\
\hline 素 & $\neq$ & $\bar{I}$ & & 前 & 4 & 次 & $\exists$ & 2 & & $\mu$ & r. & $\mathscr{g}$ \\
\hline , & + & 1 & & 記 & $n$ & 硫 & 以 & $\Xi$ & & $\Rightarrow$ & $\pi$ & $\infty$ \\
\hline$P$ & $\nu$ & | & & , & 7 & 酸 & $\bar{j}$ & $\stackrel{\varrho}{\Xi}$ & & 右 & $n$ & , \\
\hline$n$ & 比 & 根 & & 表 & 17 & 堵 & $x$ & $\overrightarrow{\vec{Q}}$ & & , & $\therefore$ & 如 \\
\hline 7 & 次 & 3 & & 中 & 1 & $\left.\right|^{\wedge}$ & $w$ & 1 & & 如 & 必 & $\exists$ \\
\hline$t$ & 硫 & 連 & & 揭 & 次 & $\#$ & $=$ & 稱 & & $\neq$ & t. & 然 \\
\hline$\forall$ & 酸 & 綪 & & $b$ & 亞 & 12 & 决 & $x$ & & 琵 & 當 & $\nu$ \\
\hline 次 & 盐 & $\pi$ & & $\not$ & 硫 & 7 & 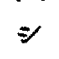 & 然 & & 迮 & $\boldsymbol{7}$ & $E$ \\
\hline 硫 & $=$ & $n$ & & $n$ & 酸 & 11 & $\vec{\gamma}$ & $\nu$ & & $\exists$ & 得 & \# \\
\hline 酸 & $\mathcal{P}$ & 硫 & & 此 & 盛 & $\perp$ & 秛 & E & & 附 & $\Rightarrow$ & 1 \\
\hline 盐 & $y$ & 素 & & 等 & $\underset{F}{F}$ & 硫 & 當 & 此 & & $\rightarrow$ & $n$ & 才 \\
\hline 八 & $F$ & , & & 埸 & 相 & 酸 & , & 名 & & n & $\tau$ & + \\
\hline 酸 & > & 酸 & & 類 & 對 & 坥 & $\tau$ & 八 & & $\neq$ & , & 1 \\
\hline 類 & \# & 化 & & , & 7. & $\vec{r}$ & , & 他 & & 事 & $=$ & $\ln$ \\
\hline . & $n$ & せ & & 式 & $\pi$ & 相 & $=$ & , & & 睯 & $\boldsymbol{P}$ & 化 \\
\hline 接 & 7 & + & & $=$ & 7 & 應 & $\mathcal{P}$ & $\mid \geqslant$ & & $\therefore$ & $\overline{7}$ & 合 \\
\hline$\pi$ & | & $\mu$ & & 於 & 以 & $\approx$ & ラ & |オ & & $\rightarrow$ & \# & 物 \\
\hline
\end{tabular}




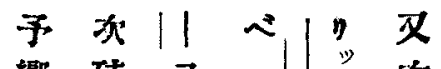
涮硫 7 n 二酸硫 $テ$ ，硫 一盐硫口十酸 諭, 酸 1 紙生盐, 1, $=$ 成 $=$ 研 $\neq\left.\right|^{y}$ 述、化究 八千 ح 恐 $\rightarrow$ 前 $\boldsymbol{P}$ $\Rightarrow \geqslant ル \exists$ 修 $n \cdots, \nu$ 巳合 如 數 三八三承 》硫 + 酸述 = 、化 $三$ 化 $~$ 乙物大銅， 》 八, 亦及 $n \bar{z}$ 硫 硫 次 酸 如 分 硫素硫化，解 酸, 酸恶制

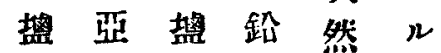
, 硫及心十 生 酸 硫 並》亞 大 $\left.\right|^{p}$ 酸 $=$ 硫 $\sim n$ 埇 數酸

$\neq$ 示硫盐

籍 弶化 梯I化|P 一 物此 せ 元 + 物 $三$ 辛 $\therefore=\approx n$ 制酸, 先 然化 =

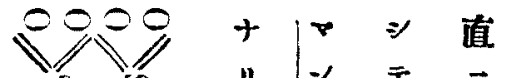
$\eta \approx F=$ \# 正 硫 $=$ = 酸 I此 盟 大 $三 \Rightarrow$ 二艋 酸 $\nexists$ 類 化 ) ○中盐 次 間 基 硫 $=$ 卜 酸 位 接 临 $大$ ～ $\exists n$ 得飞 n, 值 $\therefore 1=$ 左云亞 , > 碚 方可 酸 程 少 式=

\#還

$y$

$x$ 却 $x$

\section{积}

京 化 學 雷 誌 第 六 䢾 杂 
造䊔 八热酸和䣱非

克


造構, 盍酸 和 飽 非

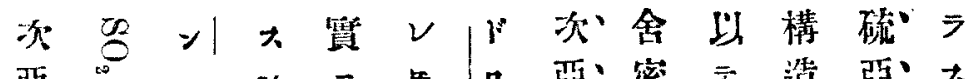
亞 硫 $尹$ 少 テ然

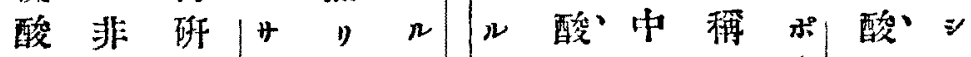

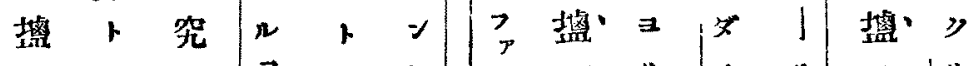

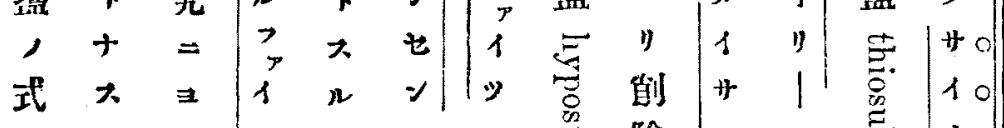

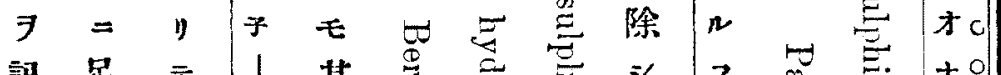

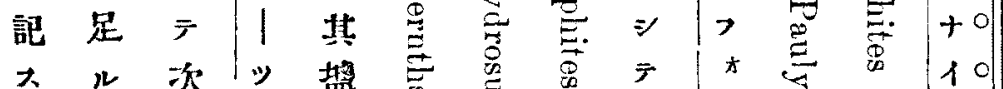

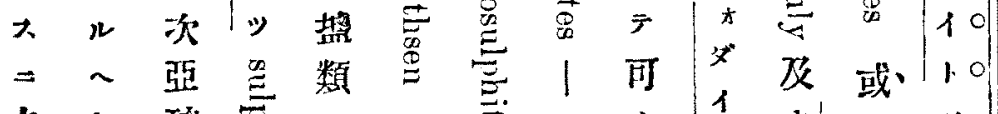

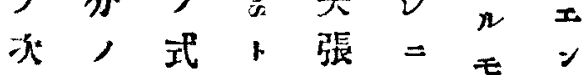
硫證八相り疑, 的

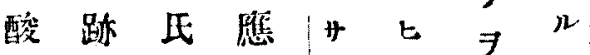
壈 二探附 $几 力$ 起昰心

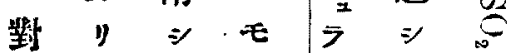
照得 $\Rightarrow, 1$,

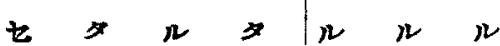

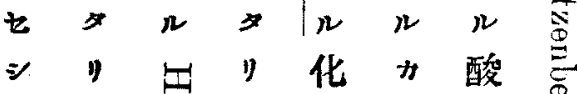
山予页合今類密 n, $\cong=$ 物 - ,

前 $ᄏ$ テ 步愳心

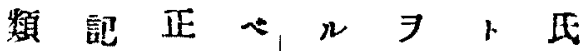

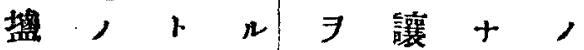

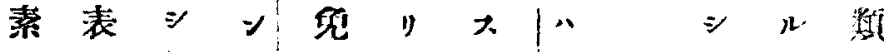
, = $I$ 七 $v \mp$ 然 1 


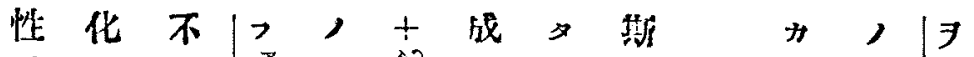

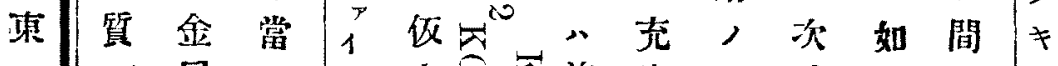
京 $\therefore$ 属 $=$ 子定运前分如硫》 $=\Rightarrow$ 化 學

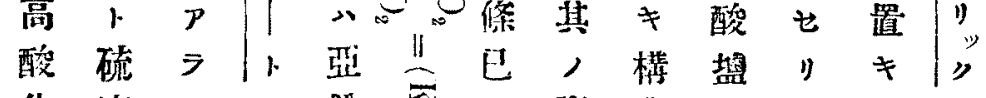
需 化素 $\# \exists$ 鉛可

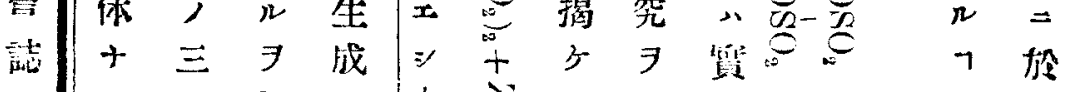
第 $n$ 二知 枀三酸 ル ル 帙 二化 $\sim$,

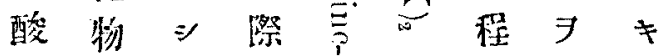

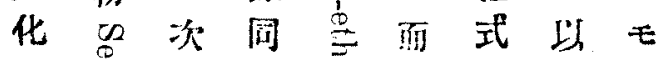

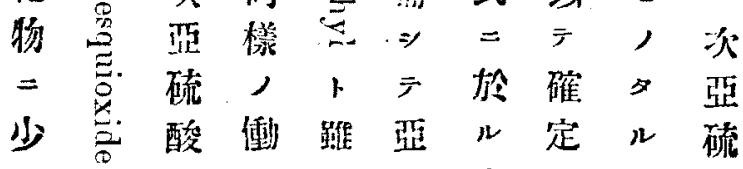

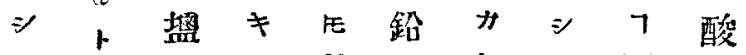
, 八 7 基, 如夕疑望 閵大之篇, 酸 $三 n+7$

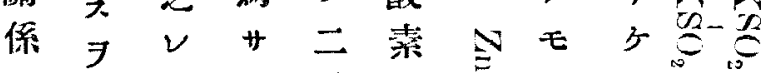
$P$ 得 $n \sim$ 式心化取芯卜比 $7 \neq 3$, 硫 $\overline{0}$ 八此

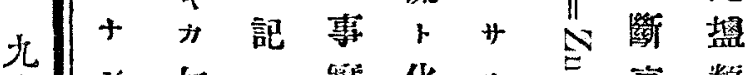
$+三$ 如 $ス$ 转 $\equiv \quad \forall=\Rightarrow$ 合 $₹ \underset{D}{D}=$,

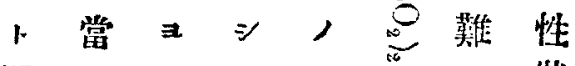

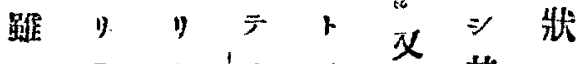
化 其酸 其心 心 生 未

次係 硫 , 酸 如 盐》 $\exists \quad z$ 硫之 酸 v 绵 马 及 亞 惡 硫 硫 酸 酸 坫 垥 及

\begin{tabular}{c|c} 
間 & n \\
$=$ & 7 \\
置 & 1 \\
7 & 3 \\
3 & 1 \\
$n$ & 1
\end{tabular}


造棈 ノ热酸和飽非

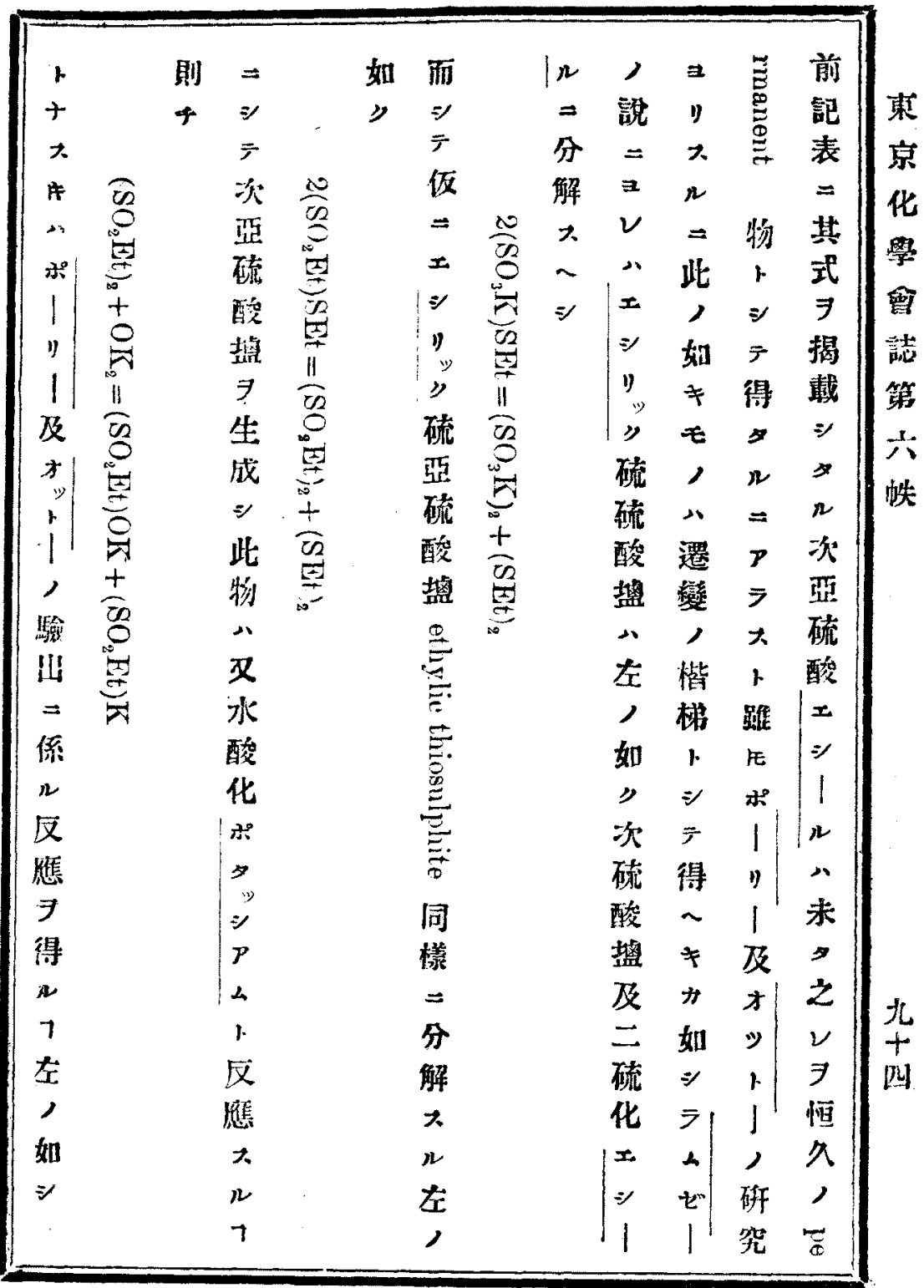




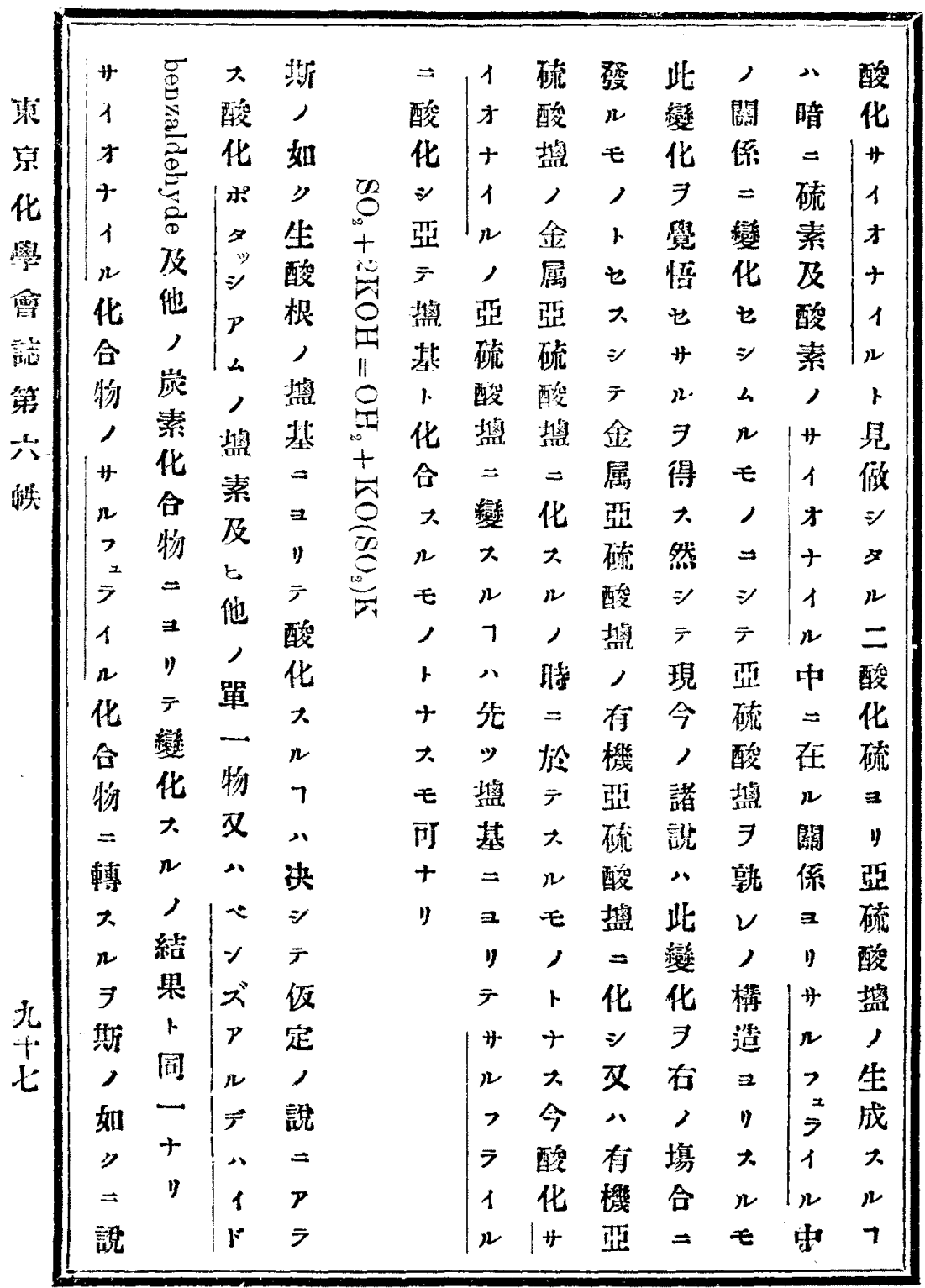


造構, 热酸和脃非

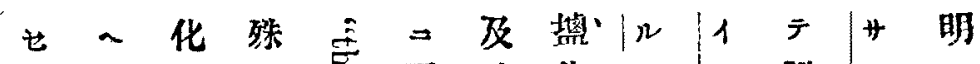

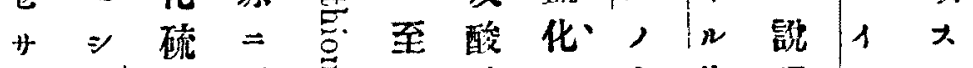

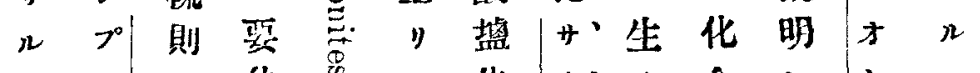

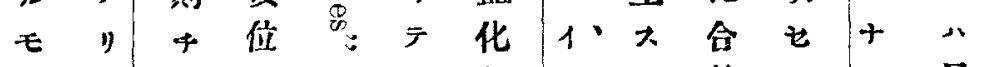

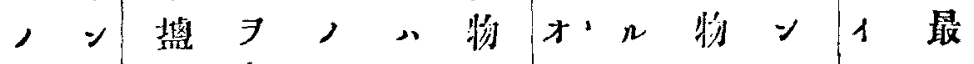

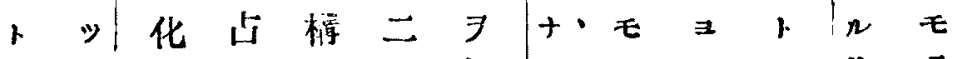

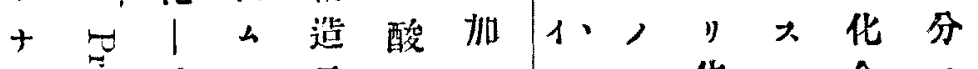

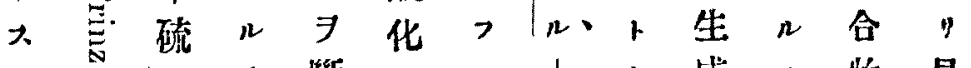

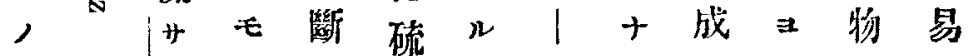

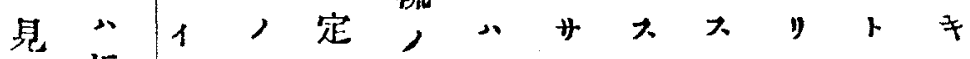

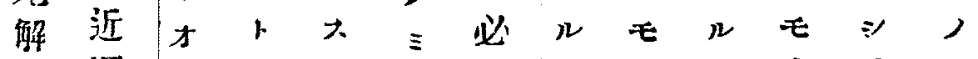

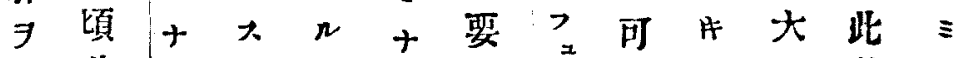
公此 1 又 $=\bar{y}=\overline{7}+\cdots \Rightarrow$ 物 +

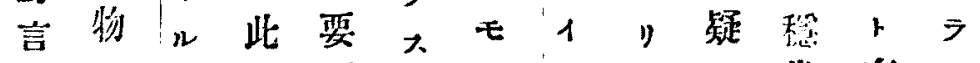

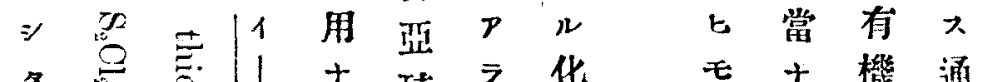
\$官 $1+$ 硫

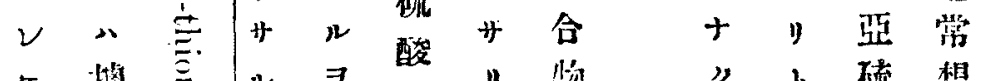

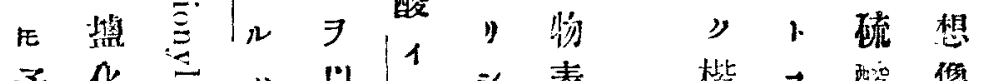
予化“江等

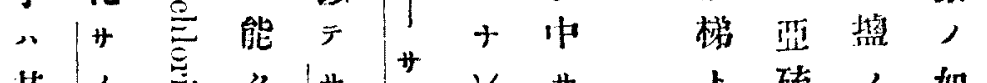
共 1 突

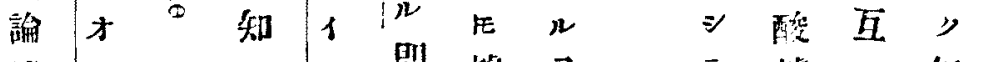

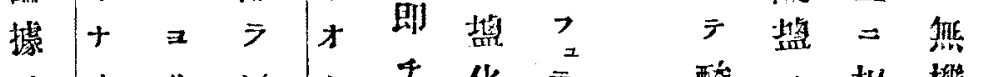
１１Ｖ＋千化 $₹$ 酸，机排

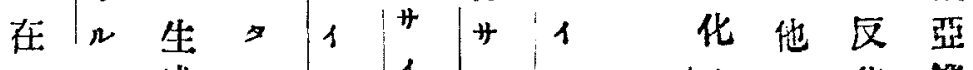

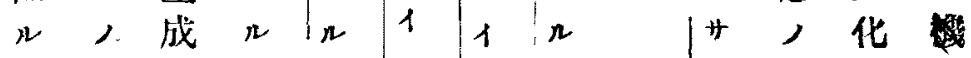

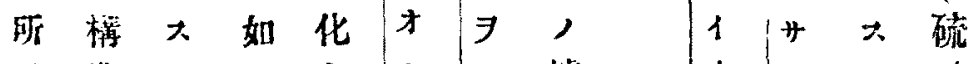
$\exists$ 造 $n \geqslant$ 合 ++ 盐

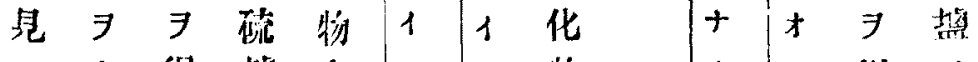

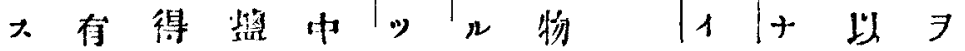


造㩐, 热酸和你非

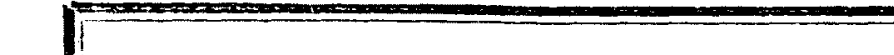

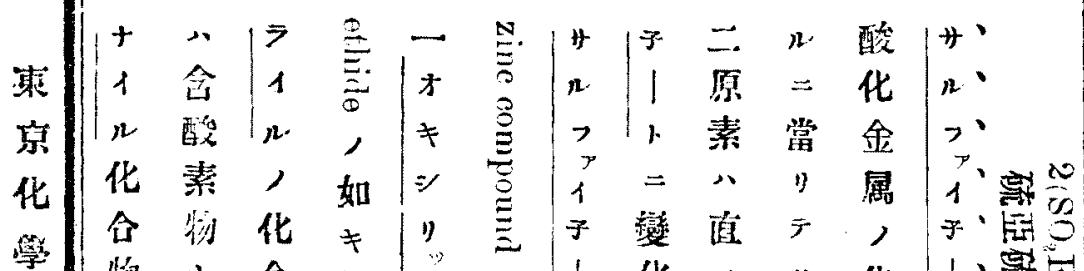

會

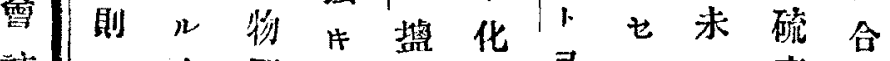

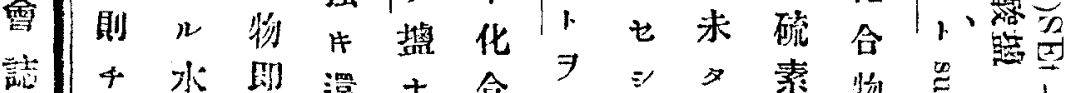

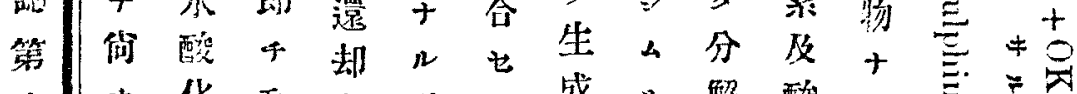

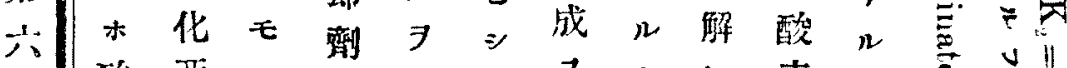

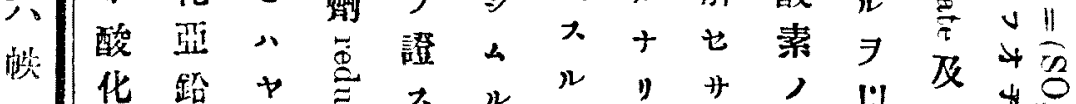

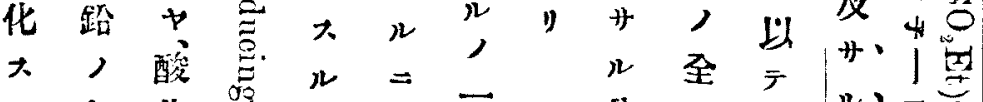

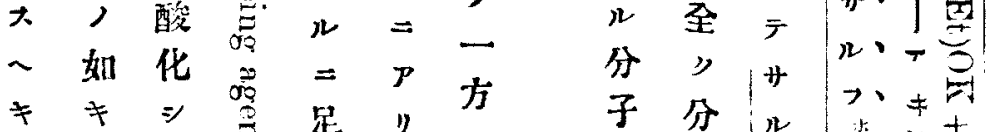

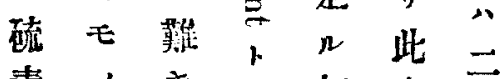
素, 踓 何 事 酸

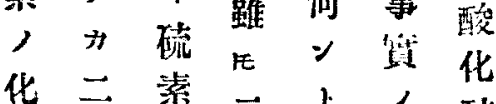
合酸, 三十 物化化化 $v=7$ $\exists$ 硫合硫、妇水 生、物硫壁口索 铚 $=$ 化

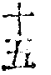
2 合生化路 ₹ 孷 $卜 \quad \Rightarrow$ 成 云 $=7$ 原 1 硫 晋

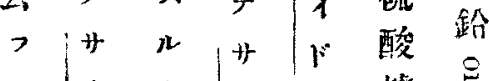
$1 / 12$ … 12

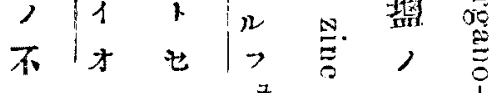
子分 $n$ 卌

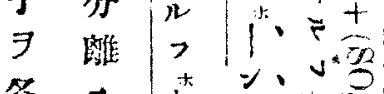

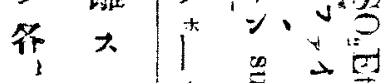
H n $17, \quad \frac{E}{5}$ 才 一 如 \#分” 上子固|\#空 $>$ 丩 定代 $7=t>$ 年 1 完 $\left.7\right|_{1} ^{7}$ 1 了大 7 级 $=$ 其 吾 $=$ 分 几 方解 八 $>$ 此 7 非 
造構, 热酸和飽非

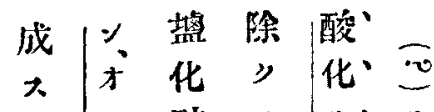

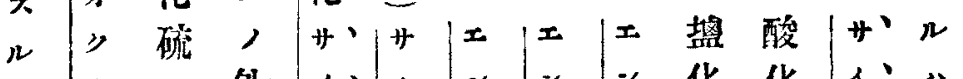

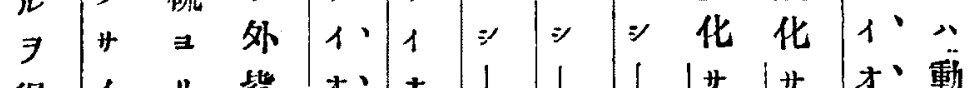

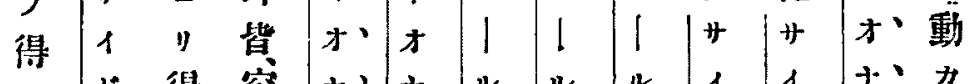

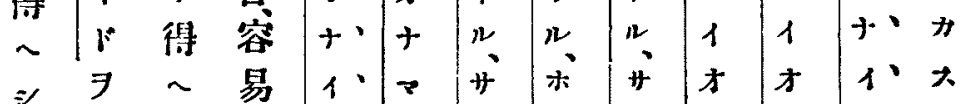

除 $5=n \cdot 1, n \geq 1++\ldots \cdot n$

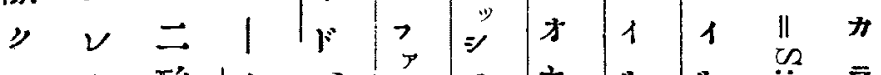

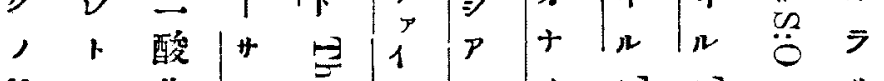

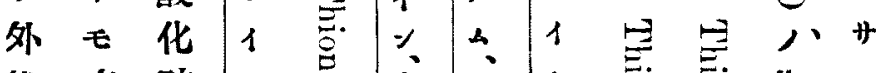

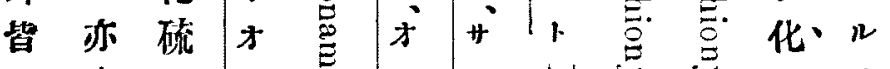

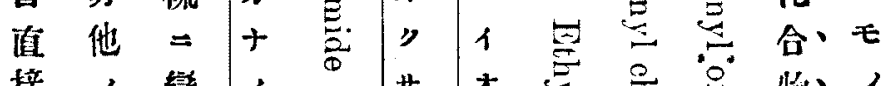

接,

八 1 七 化

間 才

接 + 出物

$=1 \sim$

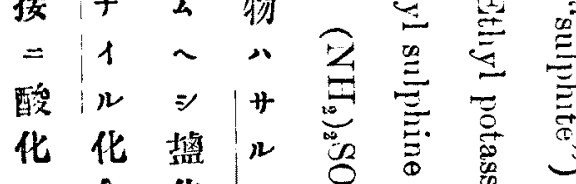

\#合 化 7

\begin{tabular}{ll|l|l}
1 & 物 & +1 & 1 \\
$\pi$ & 1 & 1 & $\%$
\end{tabular}

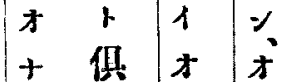

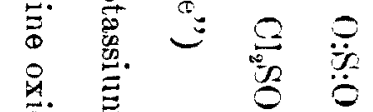

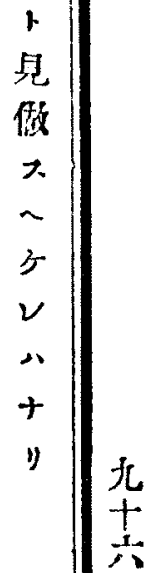

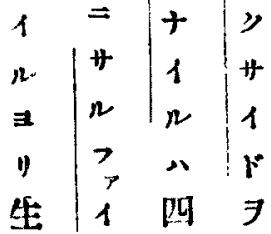

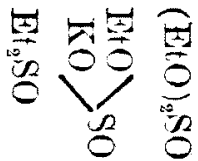


交期 $=$ F|几交及搵結卜酸, 氏

東 換 7 變

宗 $ᄏ$ へ

化士キn或々

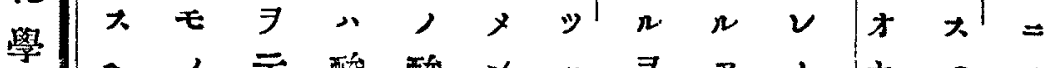

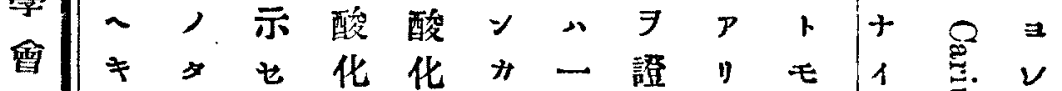

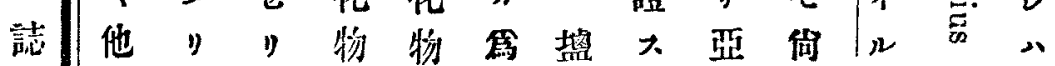

第, 蓋然, $\exists \rtimes$ 化 $x$ 硫

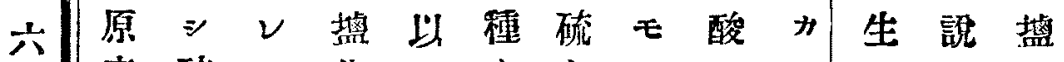

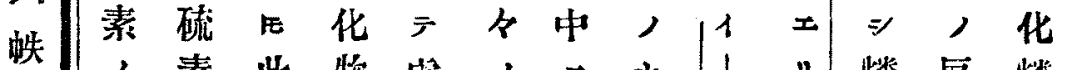
, 素此物處, $=+1$ |

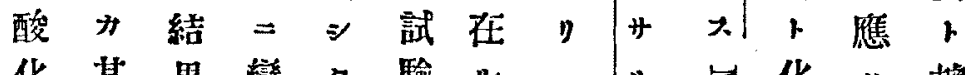
化其果戀 》驗 $\left.n\right|_{2}$ 写化八盐

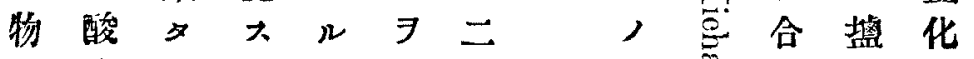
, 素 $n n=+$ 化 存 $\ni$ 就 $\exists>$ 合 大盐 $v$ 證り

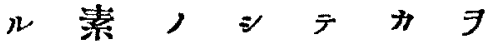
$P$ 卜 構多其之有 ル交造盐結 $ン$ 大 斗換 說化果搵n 》ス 九之川用，或！素 十 ע フコ一硫入硫

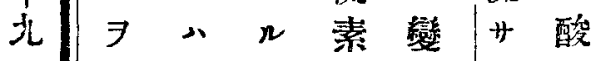
肯此乇层化 1 素 大, 敢二, 几 如 $テ$ 酸 無 + 以

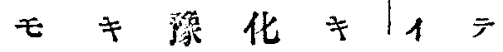
生成产 是 》三硫开

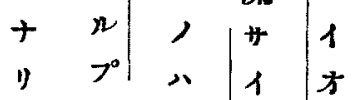
即酸才十

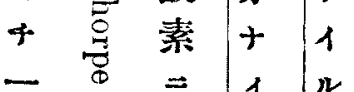
塔

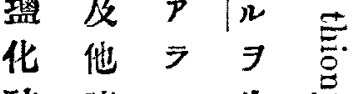
硫 諸 大生导 、氏搵女导 硫, 素大焉 , 㸴 $+\Rightarrow$ 客 硫究り $\neq$, 
造糊, 盐酸和脃非

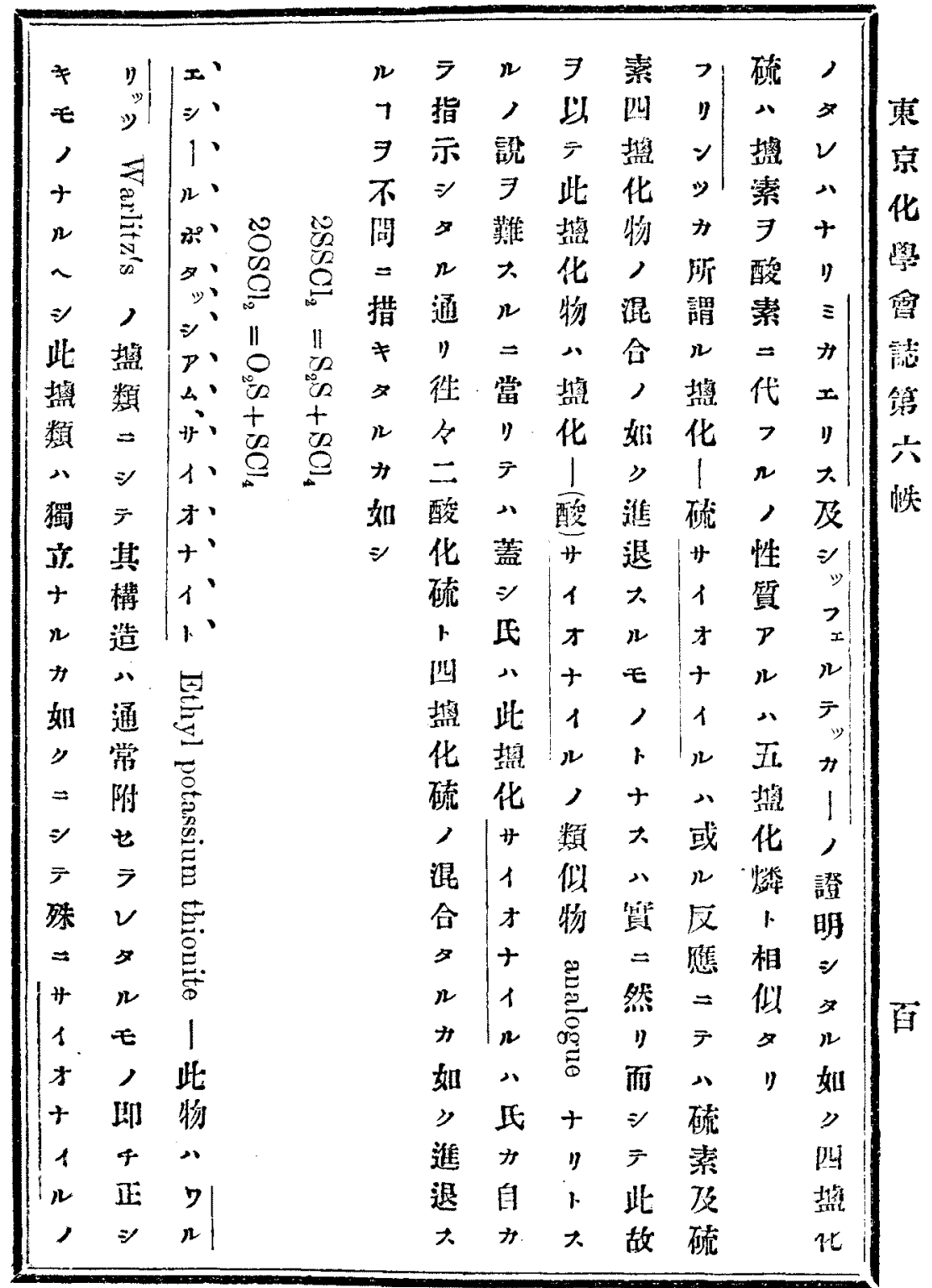




\section{造粠，盐酸和绝非}

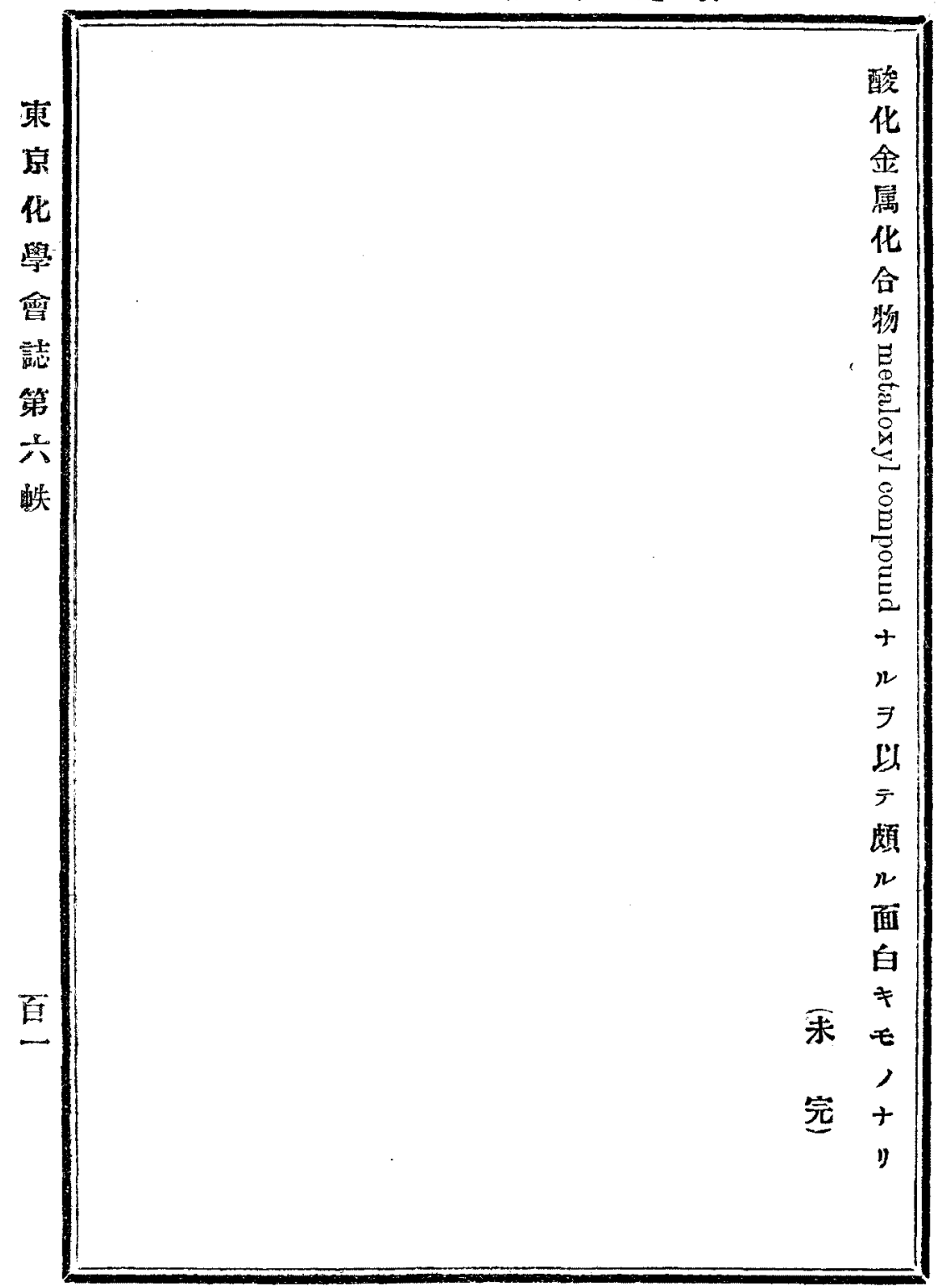

